\title{
UTILIZATION OF HEAT EXCHANGERS IN DRYING OF FISH FARM WASTES FOR THE PRODUCTION OF FEED CONCENTRATES
}

\author{
Said Elshahat Abdallah,* \\ Wael Mohamed Elmessery, $* *$ \\ Abdelfattah A. Elkeway *** and Mesbah Morgan Abdelaal ****
}

ABSTRACT

Due to increasing the prices of fish and animal feed, a big gap in feed nutrition is generated. Also the increment necessitates of the sources of animal protein creates and maximize this nutritional gap in Egypt. So the creation of local and alternative source of feed concentrates instead of import is needed. Huge quantities of small sizes of fish are thrown on land without any manipulation during fish ponds harvesting. It is necessary to process and recycle these wastes in order to be a useful component. Drying process was used in the present investigation for fish wastes treatment that adds to obtain feed concentrates with low costs (Fishmeal). Therefore, the objective of this research work is to dry a sample of the whole fish waste, by using the heat exchangers, at the experimental station of Rice Mechanization Center (RMC), Meet Eldeebah village, Kafr Elsheikh Governorate during September of the year 2015 by using a stream of hot air at different drying air velocities of 1.5, 2 and $3 \mathrm{~m} / \mathrm{s}$. The manufactured heat exchanger has the cylindrical shape. Its dimensions were of $30.48 \mathrm{~cm}$ in diameter internal, $50 \mathrm{~cm}$ in diameter external and $150 \mathrm{~cm}$ long. The heat exchanger is connected with a flat plate solar collector with the dimensions of $100 \times 100 \mathrm{~cm}$. The working medium in the heat exchanger is the hot water output of flat plate solar collector. The extreme values of thermal energy stored in water and thermal efficiency of the solar system are of 50.284 and $53.549 \%$, respectively.

Keywords: drying rate, fishmeal, heat exchanger, flat plate solar collector, fish wastes

\footnotetext{
*Associate Professor, Department of Agricultural Engineering, Faculty of Agriculture, Kafrelsheikh University, Kafr Elsheikh 33516, Egypt

**Lecturer, Department of Agricultural Engineering, Faculty of Agriculture, Kafrelsheikh University, Kafr Elsheikh 33516, Egypt

***Senior Researcher, Agricultural Engineering Research Institute, Dokki, Giza, Egypt $* * * *$ M. Sc. Student, Department of Agricultural Engineering, Faculty of Agriculture, Kafrelsheikh University, Kafr Elsheikh 33516, Egypt
} 
Maximum effectiveness of the parallel flow system was of $28.152 \%$ with the drying air velocity of $1.5 \mathrm{~m} / \mathrm{s}$, whereas for the counter flow system was of $19.46 \%$ with the drying air velocity of $2 \mathrm{~m} / \mathrm{s}$. Also, the highest values of heat energy transferred rate from water to air were of $2.21 \mathrm{~kW}$ and $2.81 \mathrm{~kW}$ with the drying air velocity of $3 \mathrm{~m} / \mathrm{s}$ for the parallel and counter flow heat exchangers, respectively. In general the counter is better than the parallel system with the maximum drying rate of $0.42 \mathrm{~kg}$ water/ $(\mathrm{kg}$ dry matter. min) at drying air velocity of $1.5 \mathrm{~m} / \mathrm{s}$. Maximum internal energy of water tank was of $6.09 \mathrm{~kJ}$ at $5.00 \mathrm{PM}$, temperature of water was of $40.6^{\circ} \mathrm{C}$ and less radiation was of $77.43 \mathrm{~W} / \mathrm{m}^{2}$. In addition, maximum exergy rate of the parallel flow system was of $2.49 \mathrm{~kW}$ with drying air velocity of $2 \mathrm{~m} / \mathrm{s}$, whereas for the counter flow system was of $0.433 \mathrm{~kW}$ with the drying air velocity of $3 \mathrm{~m} / \mathrm{s}$. Maximum specific enthalpy of the parallel and counter drier units of drying air are of 214.56 and $180 \mathrm{~kJ} / \mathrm{kg}$ at drying air velocity of $2 \mathrm{~m} / \mathrm{s}$, respectively. While specific enthalpy of drying air of counter drier unit is higher than that of parallel one at drying air velocities of 1.5 and $3 \mathrm{~m} / \mathrm{s}$ while lower at drying air velocity of $2 \mathrm{~m} / \mathrm{s}$.

\section{NOMENCLATURE}

$\mathrm{a}_{1}, \mathrm{a}_{2} \quad$ Coefficients in the heat loss terms of the efficiency, $\mathrm{W} / \mathrm{m}^{2} \mathrm{~K}$

A Total hot side or cold side heat transfer area, $\mathrm{m}^{2}$

$\mathrm{C}_{\mathrm{p}} \quad$ Specific heat, $\mathrm{J} / \mathrm{kg} \mathrm{K}$

$\mathrm{C}_{\max } \quad$ Maximum heat capacity rate of two fluids, W/K

$\mathrm{C}_{\min } \quad$ Minimum heat capacity rate of two fluids, $\mathrm{W} / \mathrm{K}$

$\mathrm{C}^{*} \quad$ Ratio of heat capacity rate of $\mathrm{C}_{\max }$ and $\mathrm{C}_{\min }$

$\mathrm{dM} \quad$ Amount of change of fish waste, $\mathrm{g}$

dt Time interval for sampling, $h$

DR Drying rate, $\mathrm{kg}$ water/(kg dry matter. min)

$h_{i}, h_{o} \quad$ Heat transfer coefficient for inside and outside flows, W $/ \mathrm{m}^{2} \mathrm{~K}$ $\mathrm{I}_{\mathrm{b}} \quad$ Solar radiation falling on the heater surface, $\mathrm{W} / \mathrm{m}^{2}$

K Thermal conductivity, W/mK

L Length, $\mathrm{m}$

LMTD Logarithmic mean temperature difference, $\mathrm{K}$

$\dot{m} \quad$ Mass airflow rate, $\mathrm{kg} / \mathrm{s}$ 
M Mass of product to be dried, $\mathrm{kg}$

$\mathrm{M}_{\mathrm{o}} \quad$ Initial moisture content, \%wb

$\mathrm{M}_{\mathrm{t}} \quad$ Moisture content at time $\mathrm{t}, \% \mathrm{wb}$

$\mathrm{M}_{\mathrm{ds}} \quad$ Mass of dry solids, $\mathrm{kg}$

$\mathrm{M}_{\mathrm{w}} \quad$ Mass of evaporated water from the product during drying day, $\mathrm{kg}$

$\mathrm{W}_{\mathrm{o}} \quad$ Initial mass of the dried product, $\mathrm{kg}$

$\mathrm{W}_{\mathrm{t}} \quad$ Mass of product to be dried at any time, $\mathrm{kg}$

$\mathrm{U} \quad$ Overall heat transfer coefficient, $\mathrm{W} / \mathrm{m}^{2} \mathrm{~K}$

NTU Number of transfer units $=\mathrm{UA} / \mathrm{C}_{\min }$

Thermal effectiveness of heat exchanger, decimal

$\mathrm{Qu}_{\mathrm{u}}$

Total heat transferred rate, $\mathrm{W}$

Qabs

Amount of useful energy, W

$\mathrm{r}$

Amount of absorbed energy, W

Radius of the cylinder heat exchanger, $\mathrm{m}$

$\mathrm{R} \quad$ Thermal resistance, $\mathrm{m}^{2} \mathrm{~K} / \mathrm{W}$

$\sum \mathrm{R} \quad$ Total thermal resistance of tube to heat flow, $\mathrm{m}^{2} \mathrm{~K} / \mathrm{W}$

Total time, $\mathrm{h}$

$\mathrm{T}_{\mathrm{amb}} \quad$ Ambient air temperature, ${ }^{\circ} \mathrm{C}$

$\mathrm{T}_{\mathrm{iw.Exg}} \quad$ Inlet water temperature of heat exchanger, ${ }^{\circ} \mathrm{C}$

$\mathrm{T}_{\text {ow.Exg }} \quad$ Outlet water temperature of heat exchanger, ${ }^{\circ} \mathrm{C}$

$\mathrm{T}_{\mathrm{o}} \quad$ Water temperature in the tubes, ${ }^{\circ} \mathrm{C}$

$\Delta \mathrm{T}_{\mathrm{M}} \quad$ True mean temperature difference between two fluids of heat exchanger, $\mathrm{K}$

UA Thermal resistance of a heat exchanger, $\mathrm{m}^{2} \mathrm{~K} / \mathrm{W}$

$\eta \quad$ Thermal efficiency of flat plate solar collector, $\%$

$\eta_{\mathrm{o}} \quad$ Optical efficiency of the water in glass collector, $\%$

$\eta_{\mathrm{s}} \quad$ Storage efficiency of flat plate solar collector, $\%$

\section{Subscripts}

$\begin{array}{llll}\text { c } & \text { Cold fluid } & \text { i, o } & \text { Inlet and outlet } \\ \text { CDU } & \text { Counter drier unit } & \text { PDU } & \text { Parallel drier unit } \\ \text { CFHE } & \begin{array}{l}\text { Counter flow heat } \\ \text { exchanger }\end{array} & \text { PFHE } & \begin{array}{l}\text { Parallel flow heat } \\ \text { exchanger }\end{array}\end{array}$




\section{INTRODUCTION}

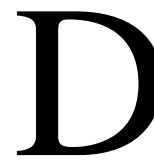
ried fish as a fishmeal, is one of the most important exported marine products in many countries such as Turkey, Iran, India wherever the fish powders containing about 55-72\% crude protein and fat content of 5\%. Fishmeal production peaked in 1994 at 30.2 million tonnes, in 2010 it was dropped to 14.8 million tonnes owing to the reduced catches of anchoveta, increased in 2011 to 19.4 million tonnes and then declined to 16.3 million tonnes in 2012. Owing to the growing demand for fishmeal and fish oil and rising prices, more fishmeals are being produced from by-products of fish, which previously were often discarded. This can affect the composition and quality of the fishmeal. According to the recent estimates, about 35 percent of world fishmeal production was obtained from fish wastes in 2012 (FAO, 2014). Fish is an important source of protein for both humans and animals where small fish and other by-products are used in the production of feed (Fishmeal) or direct feeding for aquaculture and livestock. In 2014, fishmeal production was of 15.8 million tonnes due to reduced catches of small fish. Non-official estimates of the contribution of by-products to the total volume of fishmeal and fish oil produced indicate that it is about 25$35 \%$ (FAO, 2016). The province of Kafr Elsheikh represents $40 \%$ of the fish production in Egypt (FWA, 2010). Total fish production in Egypt is about 1.06763 million tonnes and Kafr Elsheikh governorate represents almost 442000 tonnes per year of fish farms (WFC, 2011). The wasted quantities of small fish are forming low-value of fish ponds harvesting. These wastes can be used as a source of protein for animal and fish feed "Fishmeal". The international trend towards fishmeal production is noticeable in a lot of countries such as Vietnam (RIMF, 2001), but it is still not considered in Egypt. There are two types of fishmeal in Vietnam: "fish powder" produced in a traditional, artisanal way by sun drying and grinding; and fishmeal produced using an industrial process in which raw materials are cooked before being dried. Fish powder is mainly used to feed livestock (Edwards et al., 2004). Alaska produces about 1-2\% of the world fishmeal through processing fish by-products (Knapp, 2008). 
Production of fish stock is about 10 thousand tonnes; the main producers are being Iceland and Norway. The biggest producers of the other dried products are countries in Asia and Africa. The annual export of dried heads from Iceland is about 15 thousand tonnes, mainly to Nigeria, where they are used for human consumption (Arason, 2001). The fishmeal industry is likely to use geothermal steam in the processing and hopefully within a few years, geothermal steam will be transported through pipes. It can be expected that the price of oil will increase more than the local energy in the future and, therefore, it is worth paying attention to the use of locally available energy sources in the fishing industry. It was recommended that further work on optimizing the technique and a feasibility study for a freeze drying production have been done (Gudlaugsson, 1998). The fishing sector produces a huge amount of waste in fish farms and processing industries. These by-products are mainly used in the manufacture of fishmeal. However, there are other potentially valuable uses. One low investment possibility is the elaboration of agricultural products by composting the fish remains with other marine materials such as seaweed. The main purpose of their research work is to obtain a fertilizer suitable for use in organic agriculture, by composting a mix of seaweed and fish wastes (LópezMosquera et al., 2011). The Arabian Gulf has an abundant source of animal protein in the form of surplus fish according to the report (MAF, 1995). Small pelagic landings in Oman, for example, were of 41496 tonnes, (80\%) of which were sardines (Sardinella longiceps) (33054 tonnes). Waste disposal and by-products management in food processing industry pose problems towards the environmental protection and sustainability (Russ and Pittroff, 2004). There is a gap between the available quantity of green forage and the required amount of animal feed. This gap between the availability and requirement of feed is wide and the estimated shortage is 3.1 million tonnes of total digestible nutrients per year. The forage gap or the feed shortage has been partially narrowed to become 2.42 million tonnes because of using new forage resources. The drying rate is another important factor in describing the characteristics of the drying process. Double layer covered plastic greenhouse of $4 \mathrm{~cm}$ dead air space was the best to be used as a solar 
drier because of increasing temperature and humidity reduction inside the solar greenhouse drier (Abdallah, 2010). A solar drying system of a cylindrical section which consists of a flat plate solar collector, drying chamber cylindrical section and a fan was built and designed for the purpose of drying 70kg of bean crop (Gatea, 2011). Temperature is being a very important factor accelerating the process of spoilage where the spoilage reactions connecting on the death of the fish proceed at a very rapid rate where solar drying produced better quality dried fish compared to that of sun drying due to reduction in insect infestation and other contaminants (Sablani et al., 2003). Fresh fish contains up to $80 \%$ of water, fish weight loss in solar driers differs in the ecological zones of Nigeria with the North-East recording the highest value while the value of weight loss was least in South; this was attributed to the influence of relative humidity on drying (Olokor et al., 2009). The problem of the shortage of animal feed in Egypt is well recognized. Several efforts had been done to improve the nutritive value of agricultural byproducts. Rice straw, wheat straw, corn stalk, sugarcane, basse vine of broad bean, squash vine and other vegetable wastes were used for increasing the available feed (Ali, 1996). This fact reduces the wastes to be used as animal feed to fruit-vegetable and fish wastes. One of the main drawbacks of using fruit-vegetable and fish wastes in the formulation of animal diets is that their composition may be extremely variable depending on the area of production and the period of the year and reports of FAO also indicated that the quantity and quality of these wastes vary from country to country (Westendorf, 2000). Nowadays there are a lot of engineering techniques used for drying purposes of agricultural production wastes. The trend towards the exploitation of solar energy as an alternative source of energy was considered by a lot of investigators such as greenhouses as a solar energy collector for drying agricultural wastes (E1-Sahrigi et al., 1993; Abdallah, 1999; El-Keway, 2003; Eldreeny, 2015 and Elbadawy, 2016 ), solar tunnel and flat plate solar drier (Bala and Mondol 2001; Bala et al., 2001; Goddard and Perret, 2005; Dhiwahar, 2010; Montero et al., 2010; Basunia et al., 2011; Gatea, 2011; Bala and Debnath, 2012), Solar cabinet and chimney drier "mixed-mode" (Mumba, 1996; Ekechukwu and Norton 1999; 
Pangavhane et al., 2002; Vlachos et al., 2002; Sablani et al., 2003; Sankat and Mujaffar, 2004; Gbaha et al., 2007; Forson et al., 2007; Bukola and Ayoola, 2008; Afriyie et al., 2009; Jairaj et al., 2009; Ramana Murthy, 2009; Sharma et al., 2009; Fudholi et al., 2010; Banout et al., 2011; Mujaffar and Sankat, 2011; Vijaya Venkata Raman et al., 2012). On the other hand, there are limits literatures that investigate the utilization potential of the heat exchangers for drying air heating processes by solar energy. Therefore the main aim of the present research work is investigate the thermal performance of heat exchangers operated by solar energy in the drying process of fish farm wastes for the production of feed concentrates.

\section{MATERIALS AND METHODS}

\section{Experimentation}

The solar drying system is consisted of drying chamber, flat plate solar collector supplemented with parallel and counter flow heat exchangers.

\section{Drying chamber}

Drying chamber consists of greenhouse with dimensions of $2 \mathrm{~m}$ long, $1 \mathrm{~m}$ wide and $0.9 \mathrm{~m}$ height and covered all sides by polyethylene plastic, placed under shadow to avoid the effect of direct heating by solar rays in drying chamber on heat exchanger performance analysis. The drying chambers are equipped with load cells (type S, Model YZC-516C, China) with an accuracy of $50 \mathrm{~g}$ and measuring up to $500 \mathrm{~kg}_{\text {f }}$, to acknowledge the whole weight of the drying chamber and loaded fish wastes to be dried. In this investigation, the drying air was supplemented by a solar heat exchanger unit to the drying chamber through an isolated steel duct located at the top of the drying chamber greenhouse type. A suction fan powered AC (Future, Motore Asincrono Trifase; 50Hz- 0.37kW2850RPM, Italy) fixed on the opposite side at the bottom of the air chamber. Exit air velocities were adjusted by valves and calibrated by the anemometer (microprocessor digital meter with vane probe, AM 4838, Taiwan).

\section{Flat plate solar collector}

Flat plate solar collector with a wooden frame of $1 \mathrm{x} 1 \mathrm{~m}$, consists of cover plate of ordinary transparent glass $6 \mathrm{~mm}$ in thick and inside there is a heat absorbent dark colored plate to absorb the sun's rays and inner copper 
pipes (seven pipes with the dimensions of $0.9 \mathrm{~m}$ length and a diameter of $0.6 \mathrm{~cm}$ ) through which the water to be heated and the distance between each tube is $15 \mathrm{~cm}$. The product of heated water was stored in a thermally insulated tank (150 litres in capacity).

\section{Heat exchanger}

The investigated heat exchanger has two flow patterns: parallel and counter flow. Both of them consist of two parts: an internal galvanized iron conduict with a diameter of $0.3048 \mathrm{~m}, 1.5 \mathrm{~m}$ in length and $0.0009 \mathrm{~m}$ in thickness, which is overlapped with an outer galvanized iron conduict of $0.5 \mathrm{~m}$ in diameter used for solar heated water paths. The internal conduict is filled with commercial micro-wires which stand against fresh air passage. Micro-wires of iron generate airflow resistances on the fresh air that adds heat to be transferred from the hot surface to fresh air bulk. The heat exchanger is isolated from the outside with glasswool, Figure 1.

\section{Experimental procedure}

Fourteen kilograms of the small fish sizes were collected from fish ponds with the average dimensions of $3.6 \pm 1.4 \mathrm{~cm}$ length, $2 \pm 0.7 \mathrm{~cm}$ thick and weight of $19 \pm 2.88$ grams, Figure 2 from Damro village, Sedi Salim district, Kafr Elsheikh Governorate during September of 2015. They were divided into two halves, the first half for the parallel flow heat exchanger and the second half for the counter one. After that they were conveyed to the experimental station of Rice Mechanization Center (RMC) at Meet Eldeebah village, Kafr Elsheikh Governorate located at $31^{\circ} 07^{\prime} \mathrm{N}$ Latitude, 30 57'E Longitude and 20m Altitude (Abou- Zaher, 1998). The oven drying method was used for determining fish wastes moisture content at $105^{\circ} \mathrm{C}$ for $24 \mathrm{~h}$ (AOAC, 2005 and Sultana et al., 2009). The initial moisture content of the experimented sample was of $76.9 \pm 1 \%$ wb. Solar drying experiments were conducted at an averaged ambient air temperature of $31.3 \pm 4.5^{\circ} \mathrm{C}$, averaged air relative humidity of $61.8 \pm 1 \%$ (Chino Digital Humidity Meter HN-K \& HN-L18 Sensor, Japan) and intensity of solar radiation incident ranged between 560.48 and $949.78 \mathrm{~W} / \mathrm{m}^{2}$ per hour. Fish wastes were spread on the drying tray for a drying bed depth of $2 \mathrm{~cm}$ as a thin layer, inside greenhouse solar drier. The solar drier was positioned in a shaded place to avoid any additions of thermal energy from the direct solar radiation. A centrifugal suction fan 
was adjusted to provide with three levels of drying air velocities of 1.5, 2 and $3 \mathrm{~m} / \mathrm{s}$. The effect of the investigated variables on relative humidity, moisture content loss, ambient air temperature, drying rate of fish wastes, heat exchanger performance analysis and drying air temperatures inlet and outlet of the drying chamber was investigated. The readings of weight loss in the sample were recorded at an interval of 2 hours during the drying experiment by using a load cell connected with a digital screen, Figures 3 and 4.

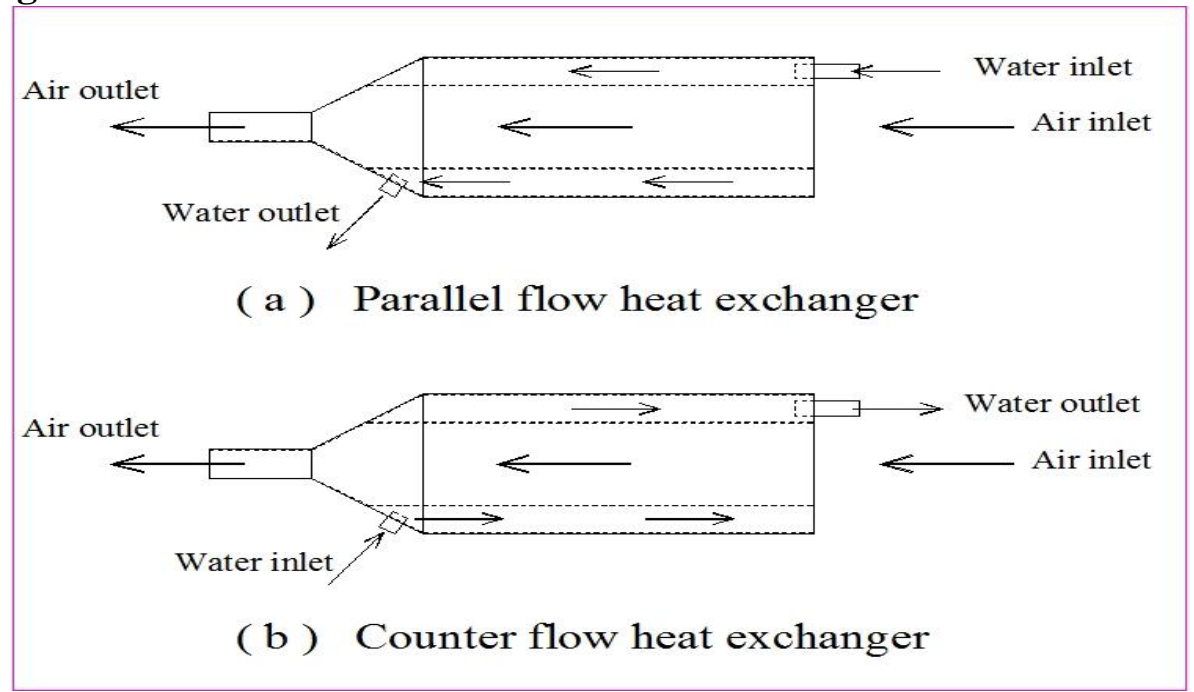

Figure 1. Fluid flow direction for both parallel (a) and counter (b) flow heat exchangers

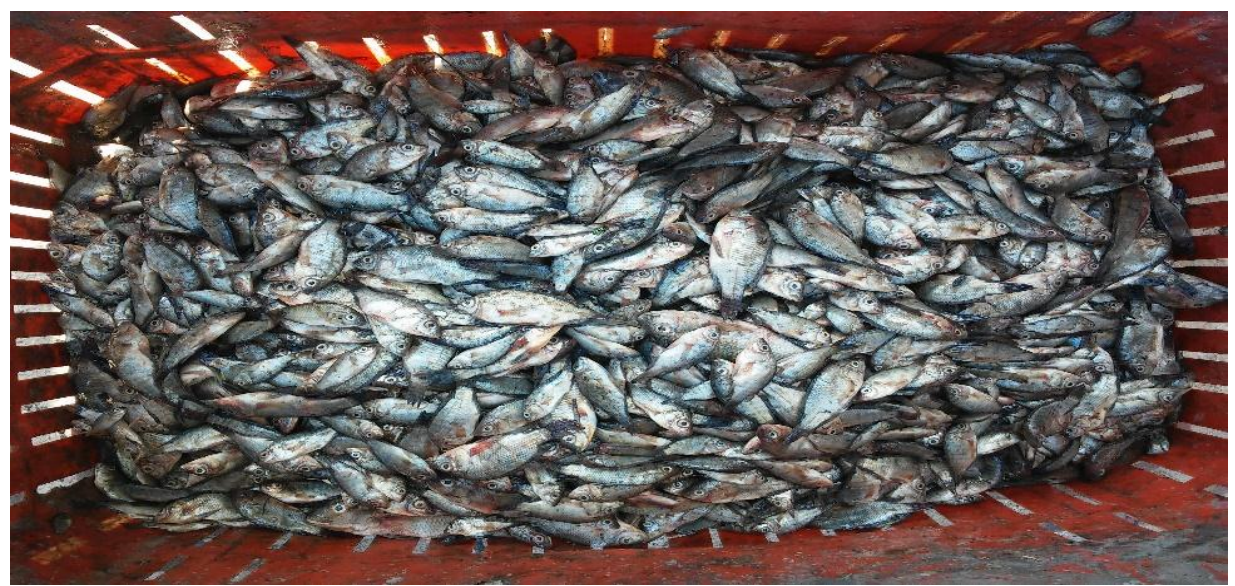

Figure 2. A photograph of fish pond wastes (fry) used in the drying experiment 


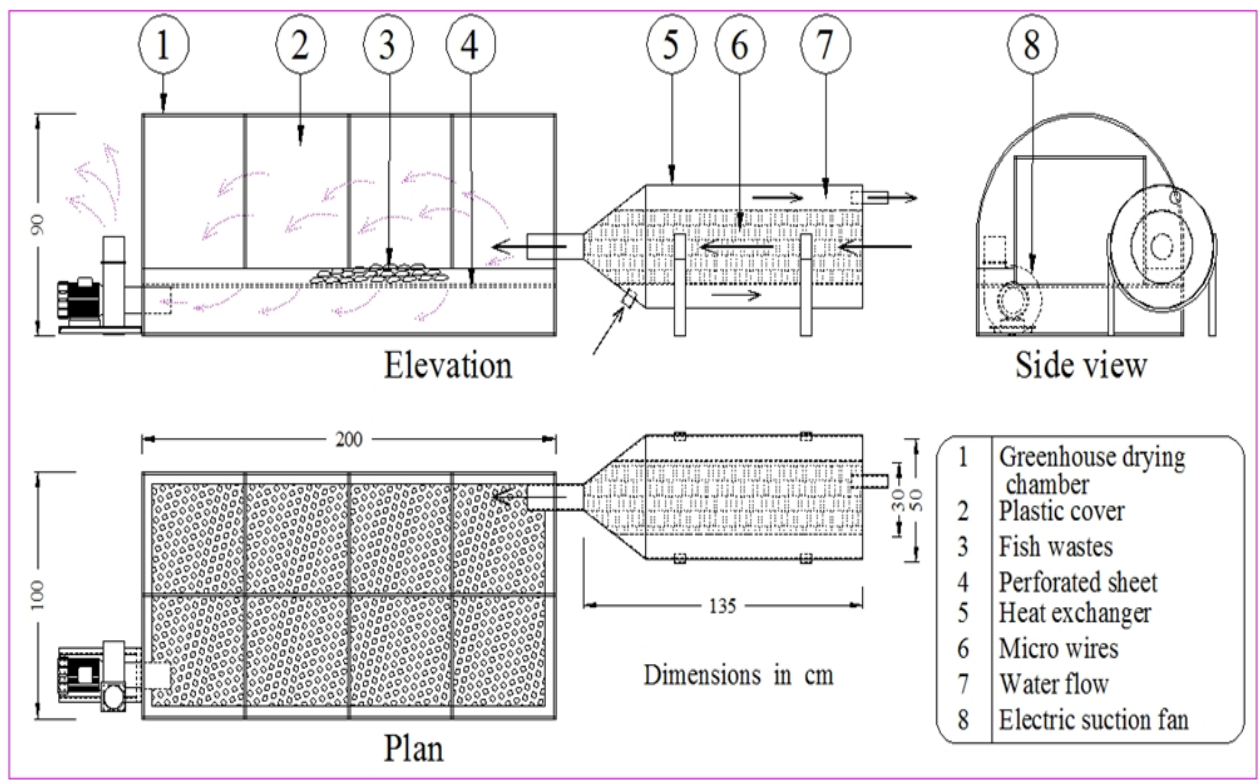

Figure 3. Perspective view of the drying chamber supplemented with the parallel and counter flow heat exchangers

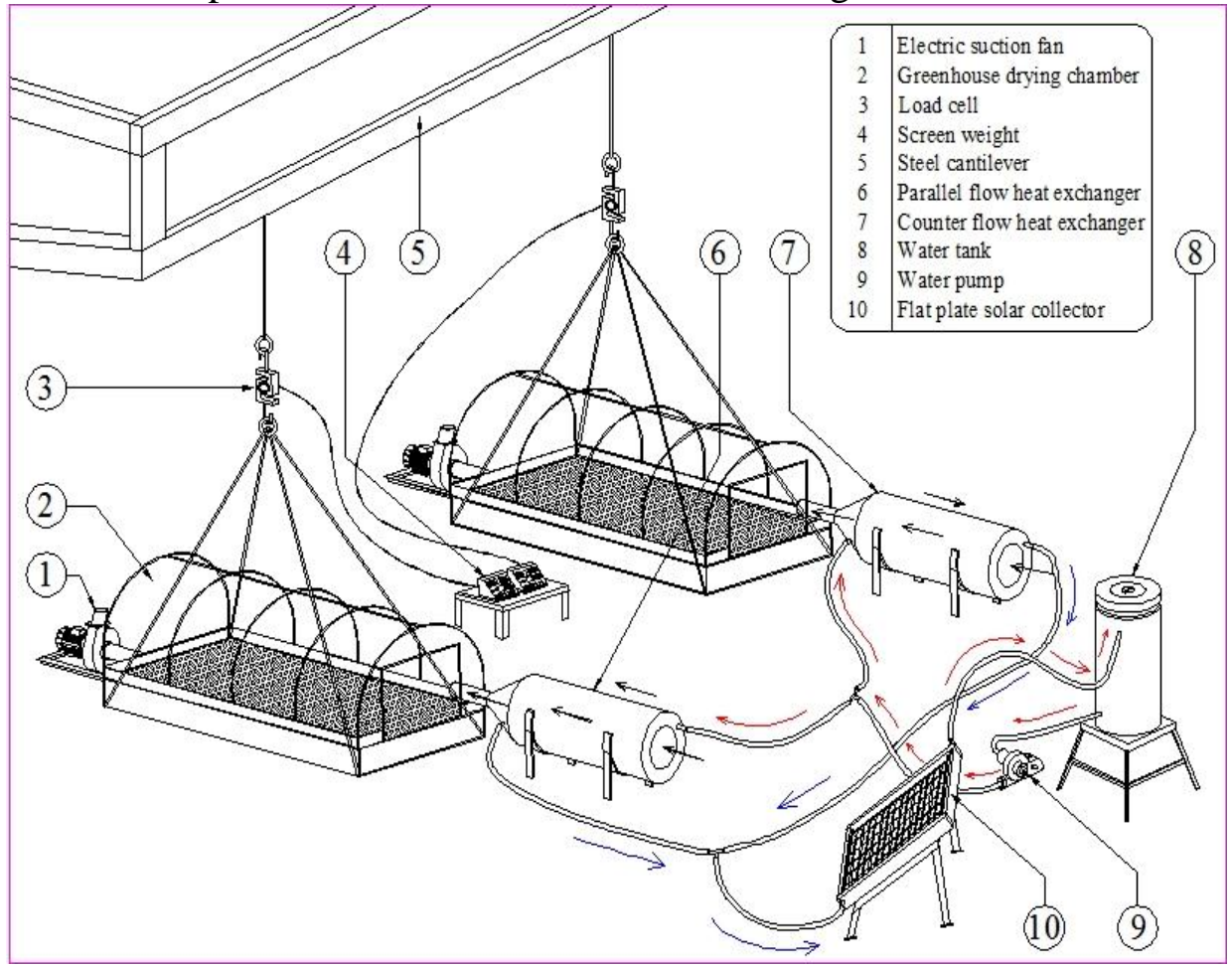

Figure 4. Schematic drawing of the whole solar drying system 


\section{Heat exchanger manufacture calculations}

Specific surface area calculations of the filling material of internal tube (drying air path):

Micro-wire was identified by a digital vernier (Digital Caliper, 0-150mm, Germany) which has a thickness of $100 \mu \mathrm{m}$, width of $290 \mu \mathrm{m}$ and a length of $0.65 \mathrm{~m}$ and the weight of it is 19.6 grams measured by a digital balance (Citizen, Model CX 220, Max.capacity 220g, Accuracy of $0.1 \mathrm{mg}$, China). The specific surface area per weight unit is $5.228 \mathrm{~m}^{2} / \mathrm{kg}$. Thermal conductivity of micro-wires is of $80 \mathrm{~W} / \mathrm{mK}$ (Incropera and DeWitt, 2002). Heat exchanger design criteria are considered by assuming that the air temperature at heat exchanger inlet is $26^{\circ} \mathrm{C}$ (average weather temperature during the experiment of period) and the required drying air temperature is $56^{\circ} \mathrm{C}$, therefore the amount of heat transferred rate is $2.7 \mathrm{~kW}$. This value requires a temperature gradient of $1.77 \mathrm{~K} / \mathrm{m}$ on heat transfer surfaces (between micro-wires and internal surface of the heat exchanger). Assuming $10 \%$ of heat transferred from water to the drying air is dissipated in the transfer path. The tube of heat exchanger obtained is $1.34 \mathrm{~m}$ in length, given by Equations $\mathbf{1}$ and $\mathbf{2}$ as follows:

$\mathrm{Q}=\mathrm{m} * \mathrm{C}_{\mathrm{p}} * \Delta \mathrm{T}$

Eqn 1

$\mathrm{Q}=\mathrm{k} * \mathrm{~A} * \Delta \mathrm{T}$

Eqn 2

Bulk density of micro-wire was calculated by the actual volume of the wire at Rice Mechanization Center Lab, which is equal to the volume of an internal conduict then, getting on the length of conduict. Overall heat transfer coefficient of heat exchanger was calculated by heat transfer total resistance, given by Equation 3 as follows:

$\mathrm{U}=\frac{1}{\mathrm{~A} * \Sigma \mathrm{K}}$

Eqn 3

\section{The LMTD method for heat exchanger performance analysis}

In heat transfer analysis of heat exchangers, the total heat transferred rate, $\mathrm{Q}$ through heat exchanger is the quantity of primary interest. Let us consider a simple counter flow or Parallel flow heat exchanger (Kakac and Liu, 2002). The form in Equation 4 may be applied to determine an energy balance for a different area element in the hot and cold fluids.

$\mathrm{Q}=\mathrm{UA} \Delta \mathrm{T}_{\mathrm{m}}$ Eqn 4 


\section{Thermal effectiveness of heat exchanger}

Heat exchanger effectiveness is defined as the ratio of the actual amount of heat transferred to the maximum possible amount of heat that could be transferred with an infinite area (Fakheri, 2006 and Guo et al., 2010) using Equations 5 and 6 as follows:

$$
\begin{aligned}
\mathrm{P}_{\mathrm{PFHE}} & =\frac{1-\exp \left[-\mathrm{NTU}\left(1+\mathrm{C}^{*}\right)\right]}{1+\mathrm{C}^{*}} \\
\mathrm{P}_{\mathrm{CFHE}} & =\frac{1-\exp \left[-\mathrm{NTU}\left(1-\mathrm{C}^{*}\right)\right]}{1-\mathrm{C}^{*} \exp \left[-\mathrm{NTU}\left(1-\mathrm{C}^{*}\right)\right]}
\end{aligned}
$$

\section{Thermal resistance of heat exchanger}

Thermal resistance of heat exchanger is commonly defined as the ratio of the temperature difference of the heat flux or the reciprocal of (UA), can be calculated by Agarwal et al., 2014 using Equation 7 as follows:

$$
\mathrm{UA}=\frac{1}{\frac{\ln \left(\frac{\mathrm{r}_{0}}{r_{\mathrm{i}}}\right)}{\frac{1}{\mathrm{~h}_{\mathrm{i}} \mathrm{A}_{\mathrm{i}}}+\frac{1}{2 \pi \mathrm{LLk}}+\frac{1}{\mathrm{~h}_{\mathrm{O}} \mathrm{A}_{\mathrm{O}}}}}
$$

\section{Thermal and storage efficiency of flat plate solar collector}

The optical efficiency of the water in glass collector under experiment is assumed to be 0.536 (Budihardjo and Morrison 2009), determined from energy gain measurements at solar noon when the radiation level and incidence angle are approximately steady. The heat loss coefficient varies with the temperature, the coefficients in the heat loss terms of the efficiency equation were determined by testing individual tubes (Marco et al., 2015), given by Equation 8. The storage efficiency of flat plate solar collector is the ratio between the amount of useful energy and the amount of absorbed energy is given by Equation 9.

$$
\begin{aligned}
& \eta=\eta_{0}-a_{1} \frac{T_{0}-T_{a m b}}{I_{b}}-a_{2} \frac{\left(T_{0}-T_{a m b}\right)^{2}}{I_{b}} \\
& \eta_{\mathrm{s}}=\frac{Q_{u}}{Q_{a b s}}
\end{aligned}
$$

\section{Instantaneous moisture content (Mt)}

To evaluate the performance of each drying unit, a methodology proposed by Leon et al., $\mathbf{2 0 0 2}$ was used in this study. The instantaneous moisture 
content on wet basis at any time can be calculated by the following equation:

$M_{t}=\left[\left(M_{\circ}+1\right) \frac{w_{t}}{w_{0}}\right]-1$

Eqn 10

\section{Drying rate}

Drying rate (DR) was calculated according to Banout et al., 2011; Michael Ayodele and Adesoji Matthew, 2012 and Darvishi et al., 2013 using Equation 11 as follows:

$\mathrm{DR}=\left(\frac{\mathrm{dM}}{\mathrm{dt}}\right)=\left(\frac{\mathrm{M}_{\mathrm{w}}}{\mathrm{M}_{\mathrm{d} s} \mathrm{t}}\right)$

Eqn 11

\section{RESULTS AND DISCUSSION}

The incident solar radiation on a horizontal surface of the drying chamber and ambient air temperatures were recorded, Figure 5. The drying process starts from 9:00AM to 9:00PM for all the investigated variables. Solar radiation rises up to a maximum value of 743.843, 783.7833 and $895.1 \mathrm{~W} / \mathrm{m}^{2}$ at $11: 00 \mathrm{AM}$ during the experimentation for $1.5,2$ and $3 \mathrm{~m} / \mathrm{s}$ drying air velocity, respectively. Figure 6 shows the inverse relationship between the ambient air relative humidity and ambient air temperature. As the temperature increases from 30.06 to $34^{\circ} \mathrm{C}$, the air relative humidity decreases from 63.43 to $53.27 \%$ during the period from 9.00AM to $3.00 \mathrm{PM}$ at drying air velocity of $1.5 \mathrm{~m} / \mathrm{s}$. The same behavior was noticed at the other drying air velocities of 2 and $3 \mathrm{~m} / \mathrm{s}$.

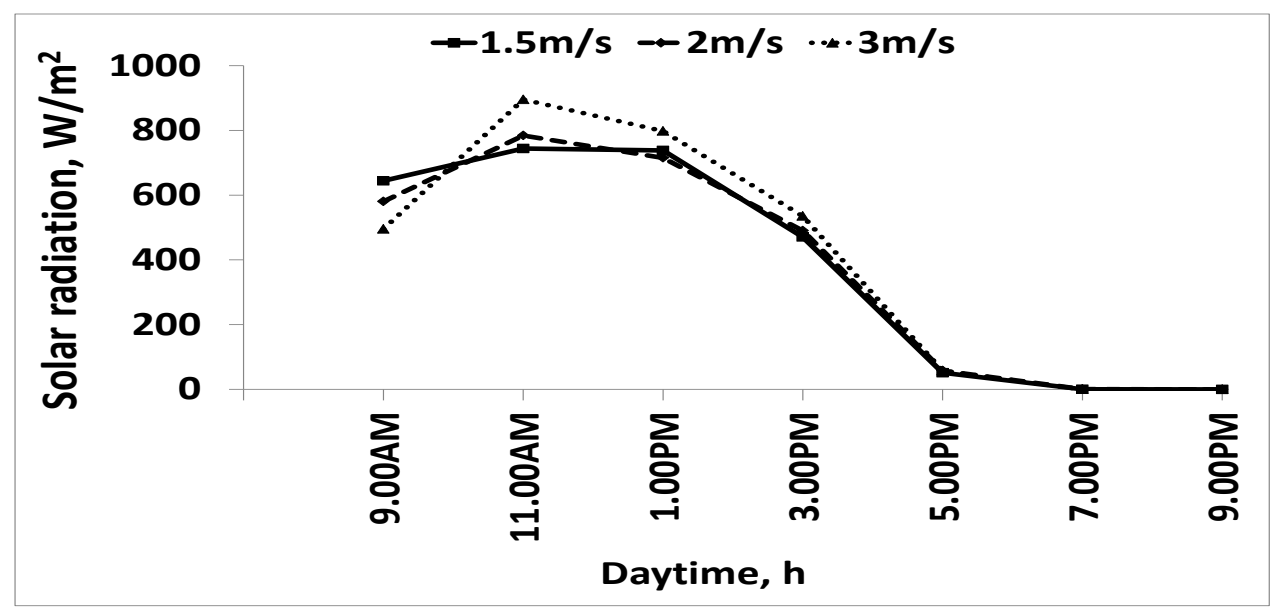

Figure 5. Variations of solar radiation incident throughout the whole drying experiment 


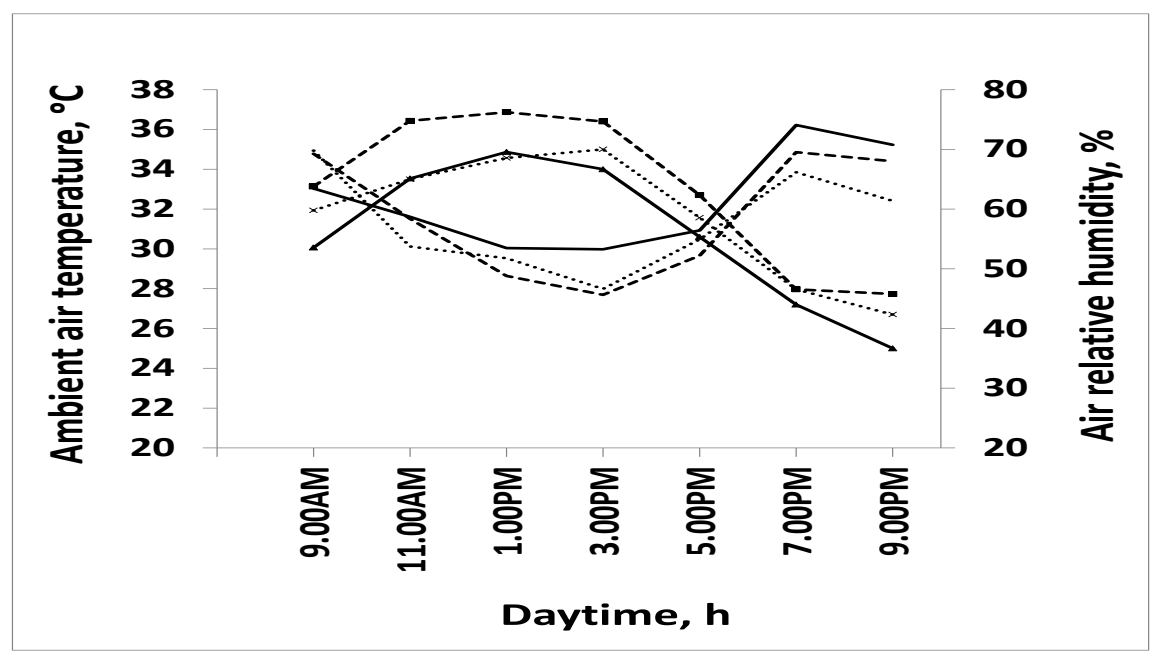

Figure 6. Ambient air temperature and air relative humidity as related to daytime during the experimental work

Figure 7 shows that the temperature of water entering the heat exchanger increased gradually during the period from 5.00PM to 7.00PM, after that the temperature decreases gradually to be stable until reached 9.00PM. The water temperature decreases dramatically due to the high consumption of the stored energy by water reservoir tank. The temperature of the water outlet of the counter flow heat exchanger is lower than that in the parallel system during the period from 9:00AM to 9:00PM due to thermal energy loss of hot water and gaining of the drying air with the drying air velocity of $1.5 \mathrm{~m} / \mathrm{s}$, The same behavior was found at the other drying air velocities of 2 and $3 \mathrm{~m} / \mathrm{s}$, during the period of drying. Figure 8 shows that, at drying air velocity of $1.5 \mathrm{~m} / \mathrm{s}$, the drying air temperature reached its highest values for both parallel and counter flow heat exchangers of 39.1 and $42.5^{\circ} \mathrm{C}$, respectively. The same behavior was found at drying air velocities of 2 and $3 \mathrm{~m} / \mathrm{s}$. The drying chamber temperature increases with the increase of drying air temperature and this leads to decrease the air relative humidity and reduces the moisture content of fish on the drying tray that can be noticed on the digital panel of the load cell as weight reduction. The counter flow heat exchanger achieved the highest values of moisture content reduction if compared to the parallel one for all the investigated drying air velocities. 

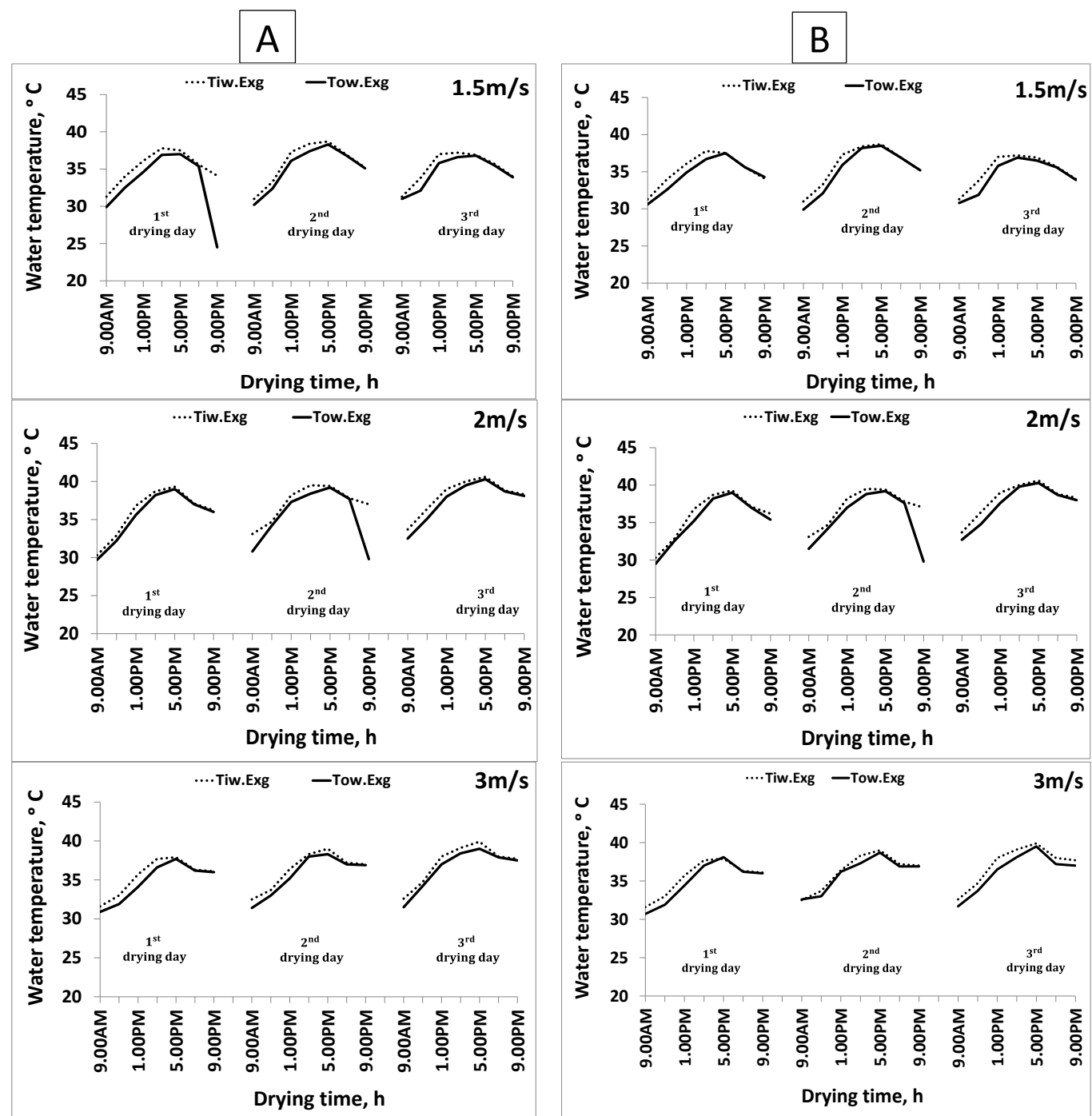

Figure 7. The influence of water temperature on the drying air temperature for both the parallel (A) and counter (B) flow heat exchangers at different drying air velocities

Figure 9 shows the evolution of fish wastes drying rate versus drying time. Drying rate of fish wastes was decreased continuously with the progress of drying time due to the reduction in fish wastes moisture content. There are different drying curve profiles; the drying rate for the first drying day is higher than that of the second drying day due to the cohesion strength of the water molecules with fish dried and increases with the drying time until the equilibrium moisture content of $9 \pm 1.74 \%$ wb is reached. 

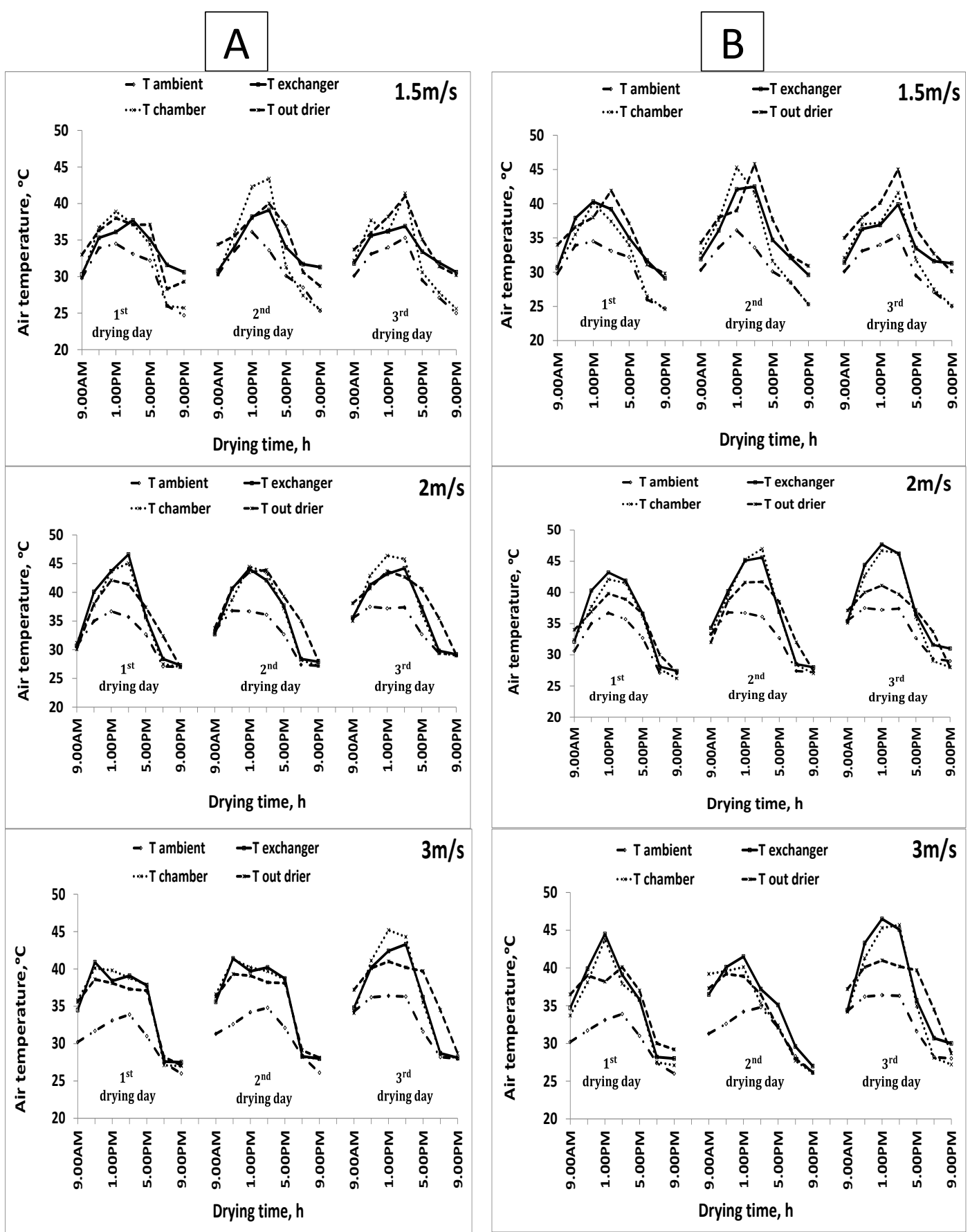

Figure 8. Hourly variations of air temperature inside and outside solar drying system for both parallel (A) and counter (B) flow heat exchangers at different drying air velocities 


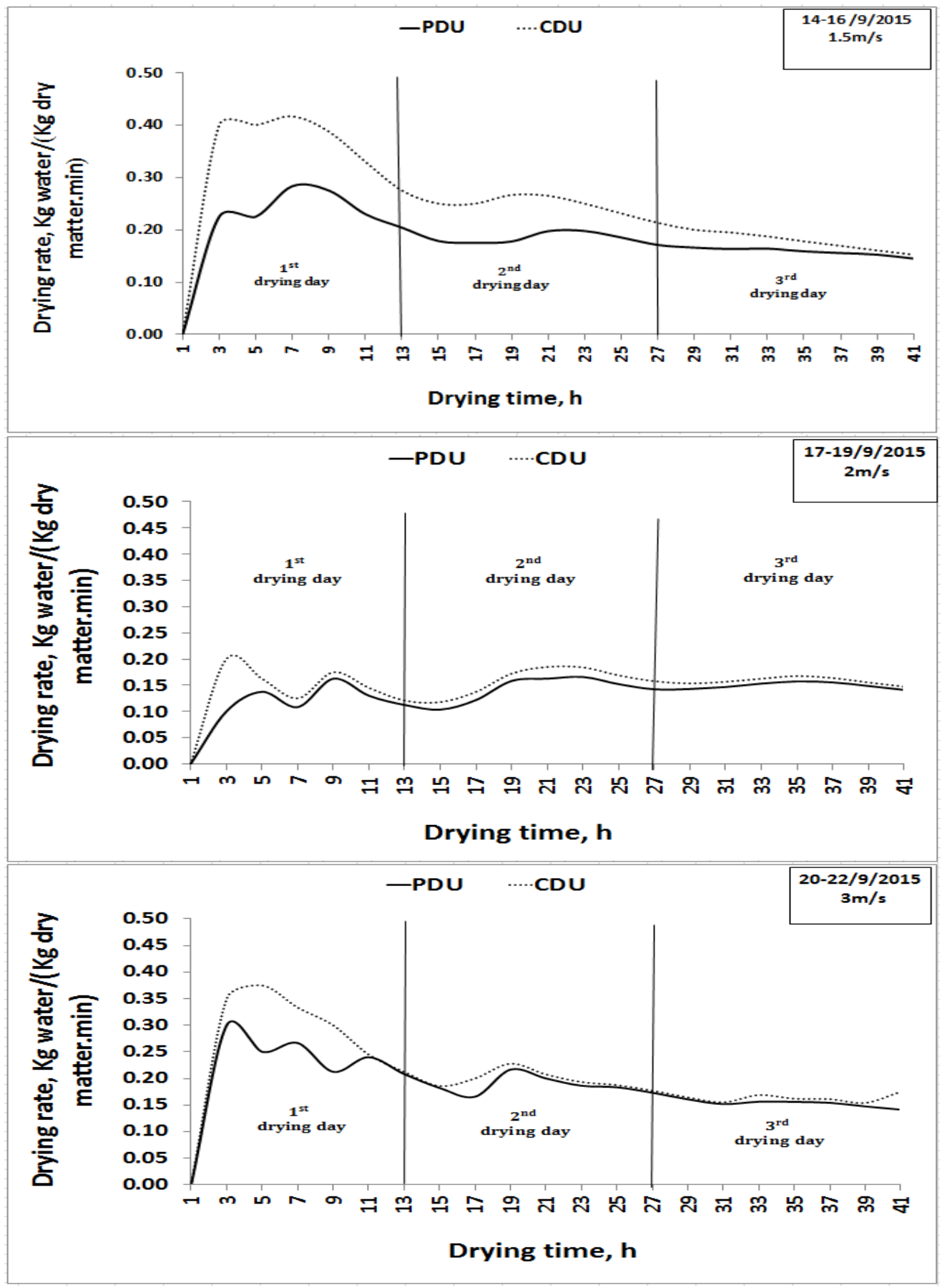

Figure 9. Drying rate as a function of drying time at different drying air velocities for both the parallel and counter drier units 
In addition, the drying rate of counter drier unit (CDU) is higher than that of the parallel drier unit (PDU) at all drying air velocities because drying air temperature of counter system is higher than that of parallel system. From the drying curves, it is evident that the highest drying rates occurred in case of CDU. Since the drying rates at drying air velocity of $1.5 \mathrm{~m} / \mathrm{s}$ in PDU and CDU are of 0.28 and $0.42 \mathrm{~kg}$ water $/(\mathrm{kg}$ dry matter. min) respectively. Whereas the final moisture content of 11.43 and $6.43 \% \mathrm{wb}$ is reached after three days of drying for the PDU and the CDU respectively. The same trend was observed at drying air velocities of 2 and $3 \mathrm{~m} / \mathrm{s}$. These results are corresponded to the observations reported by Elbadawy, 2016. Figures 10 shows the variations of moisture content of fish wastes over drying process time at different levels of drying air velocities. It is observed that, the moisture content decreases tremendously with the drying time. The reduction rate of fish wastes moisture content was increased as the drying air velocity rises. There is a significant difference between the parallel and counter flow systems at drying air velocity of $1.5 \mathrm{~m} / \mathrm{s}$ and this difference begins to be less with the increase of drying air velocity. Moreover, the reduction rates of fish wastes moisture content of counter drier unit were higher than that of the parallel drier unit throughout the period of drying experiment.

The maximum averaged value of energy stored efficiency of the water is $50.284 \%$ at useful energy of $240 \mathrm{~W}$ during the drying process. A significant reduction of the storage efficiency was noticed due to continuous consumption of energy stored during the drying process at 7:00PM, Figure 11. The maximum average value thermal efficiency of flat plate solar collector obtained is $53.549 \%$ at ambient air temperature of $33.9^{\circ} \mathrm{C}$ and solar radiation of $743.843 \mathrm{~W} / \mathrm{m}^{2}$ at $11.00 \mathrm{AM}$, Figure 12 . The internal energy of water stored at the three experimented drying air velocities is depicted in Figure 13. For the second drying day and drying air velocity of $1.5 \mathrm{~m} / \mathrm{s}$, the internal energy of the water reached its maxima of $5.85 \mathrm{~kJ}$ at $3.00 \mathrm{PM}$, water temperature was of $39^{\circ} \mathrm{C}$ and solar radiation of $609.3 \mathrm{~W} / \mathrm{m}^{2}$. Moreover, for the third drying day and at drying air velocity of $2 \mathrm{~m} / \mathrm{s}$, its value was of $6.09 \mathrm{~kJ}$ at 5:00PM, water temperature of $40.6^{\circ} \mathrm{C}$ and solar radiation of $77.43 \mathrm{~W} / \mathrm{m}^{2}$. While for drying air velocity of $3 \mathrm{~m} / \mathrm{s}$ it was of $6 \mathrm{~kJ}$ at 5:00PM, water temperature of $40^{\circ} \mathrm{C}$ and $63.7 \mathrm{~W} / \mathrm{m}^{2}$ solar radiation. 


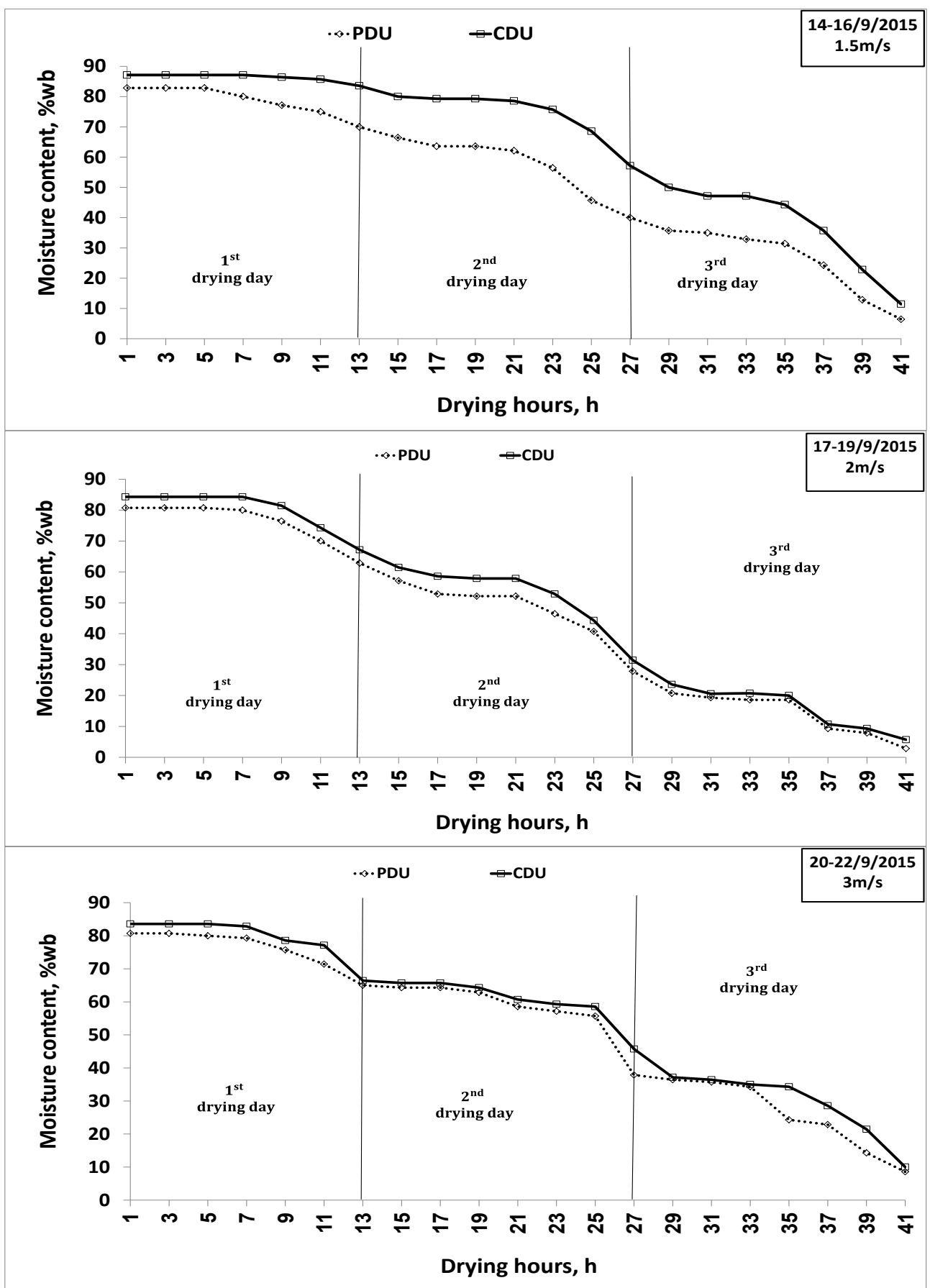

Figure 10. Evolution of fish wastes moisture content as affected by drying hours for both the parallel and counter drier units at different drying air velocities 
It can be concluded that the highest internal energy was obtained at the end of drying day at 5.00PM. Exergy summation is the exergy gained by drying chamber greenhouse. It is observed from Figure 14 that the maximum exergy rate at drying air velocity of $1.5 \mathrm{~m} / \mathrm{s}$ was of 0.08314 and $0.1356 \mathrm{~kW}$ for parallel and counter drier units, respectively. Moreover, at drying air velocity of $2 \mathrm{~m} / \mathrm{s}$, its value was of 2.497 and $0.225 \mathrm{~kW}$. While at drying air velocity of $3 \mathrm{~m} / \mathrm{s}$, its value was of 0.303 and $0.433 \mathrm{~kW}$. The specific enthalpy inside the drying chamber has higher values than that of the ambient specific enthalpy at all drying air velocities. Figure 15 shows the maximum values of specific enthalpy of 86.32, 214.56 and $121.06 \mathrm{~kJ} / \mathrm{kg}$ inside the solar drier at drying air velocities of $1.5,2$ and $3 \mathrm{~m} / \mathrm{s}$, respectively, for the parallel drier unit. While for the counter drier unit, its values were of $115.69,180$ and $135.14 \mathrm{~kJ} / \mathrm{kg}$.

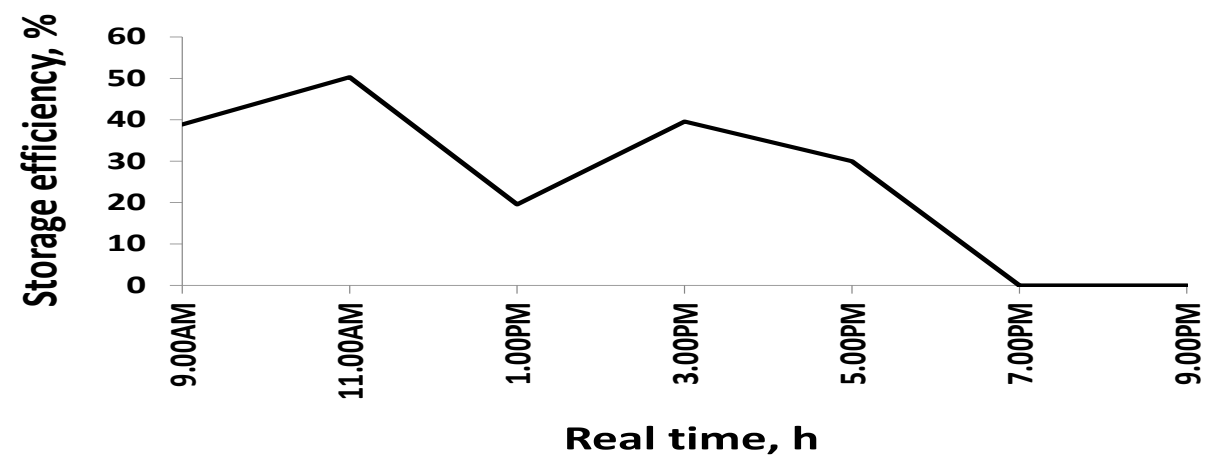

Figure 11. The averaged storage efficiency of flat plate solar collector

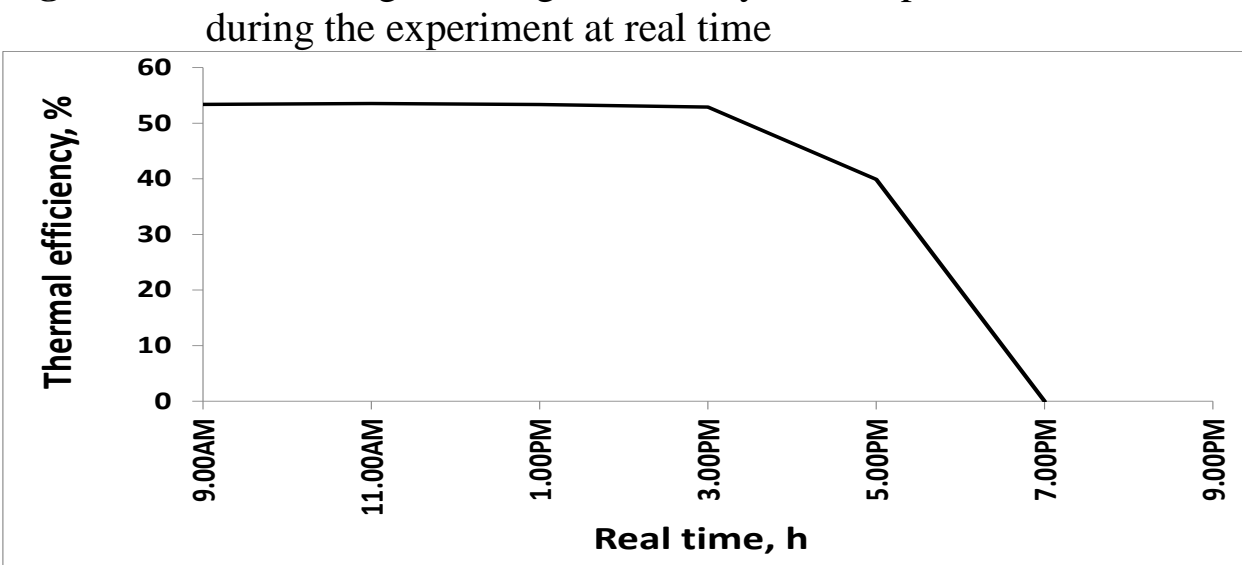

Figure 12. Thermal efficiency of flat plate solar collector during the experiment at real time 


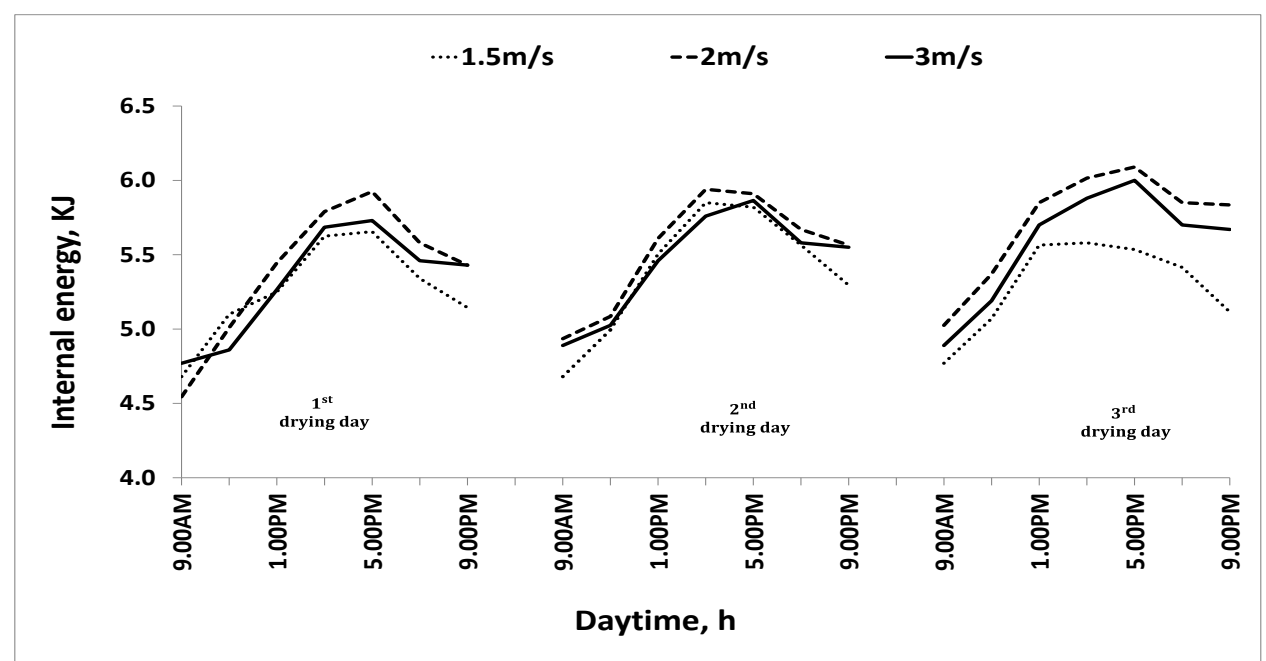

Figure 13. The effect of ambient temperature and solar radiation on internal energy of water tank at different drying air velocities

In general, the specific enthalpy of drying air increases with the increase of drying air velocity. The ambient air has higher latent specific enthalpy than that of air inside the parallel and counter drier units. In contrast, the sensible specific enthalpy of the air inside parallel and counter drier units has higher values than that of the ambient air. The maximum effectiveness of heat exchanger over the drying time, at drying air velocity of $1.5 \mathrm{~m} / \mathrm{s}$, was of 0.282 at the end of the first drying day in the parallel flow heat exchanger at 9:00PM, Figure 16. While for the counter flow heat exchanger, it was of 0.0562 for the third drying day at 11:00AM. At drying air velocity of $2 \mathrm{~m} / \mathrm{s}$, the maximum effectiveness of the counter flow heat exchanger was of 0.195 at the end of the second drying day. In general the parallel system had the highest effectiveness at drying air velocity of $1.5 \mathrm{~m} / \mathrm{s}$ but for the counter system, the highest effectiveness was achieved at drying air velocity of $2 \mathrm{~m} / \mathrm{s}$. The thermal resistance in the counter flow heat exchanger is less than that of the parallel flow heat exchanger for the three drying air velocities, Figure 17. The thermal resistance begins to increase at the beginning of the drying process and decreases with the evolution of drying time due to the high water temperature emerging from the collector and the input to heat exchanger. Consequently, the counter flow system is better than the parallel one for enhancement of the thermal efficiency of the solar drying system. 


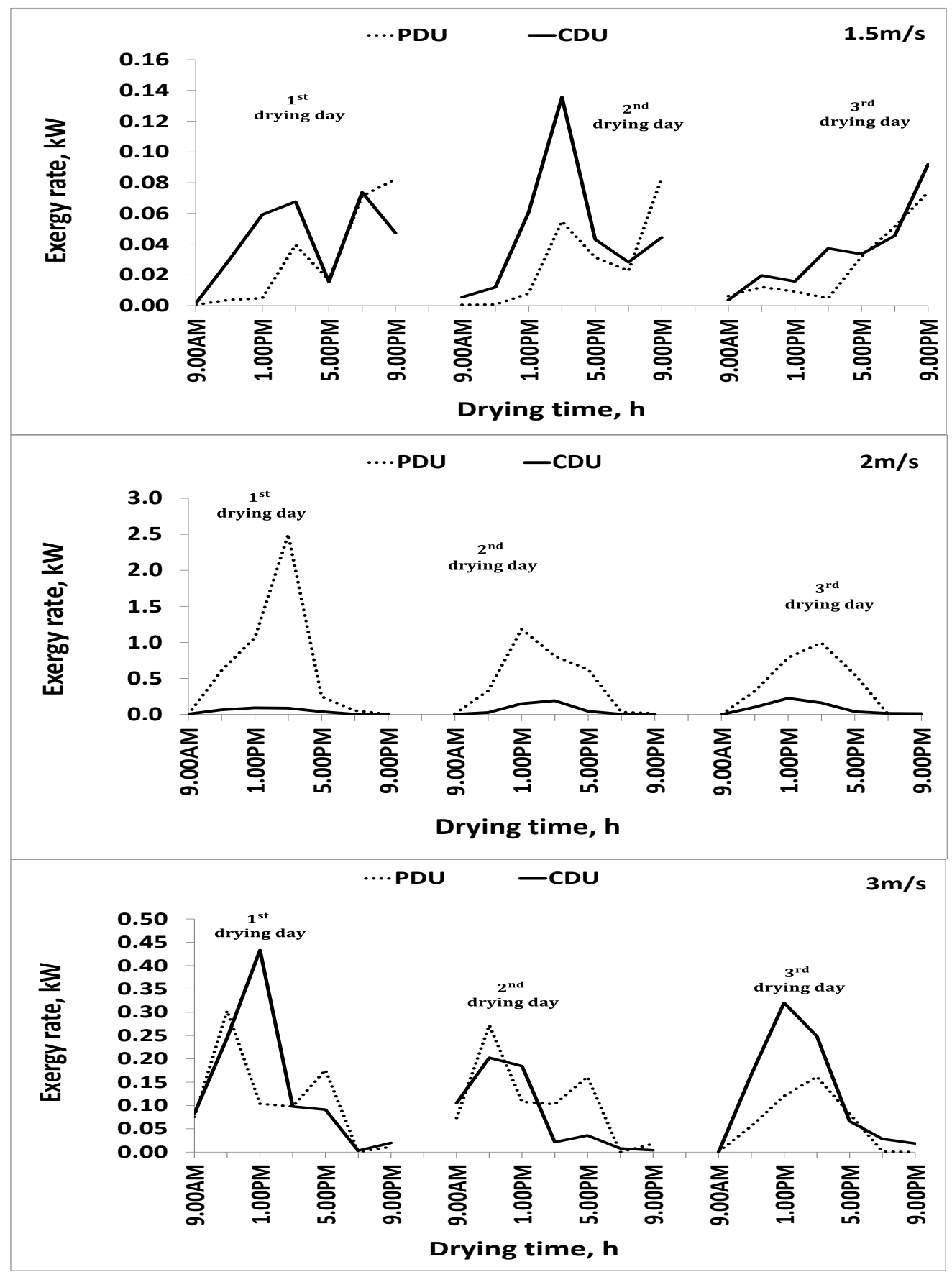

Figure 14. Exergy rate as a function of drying time inside drying chamber at different drying air velocities for both the parallel and counter drier units 


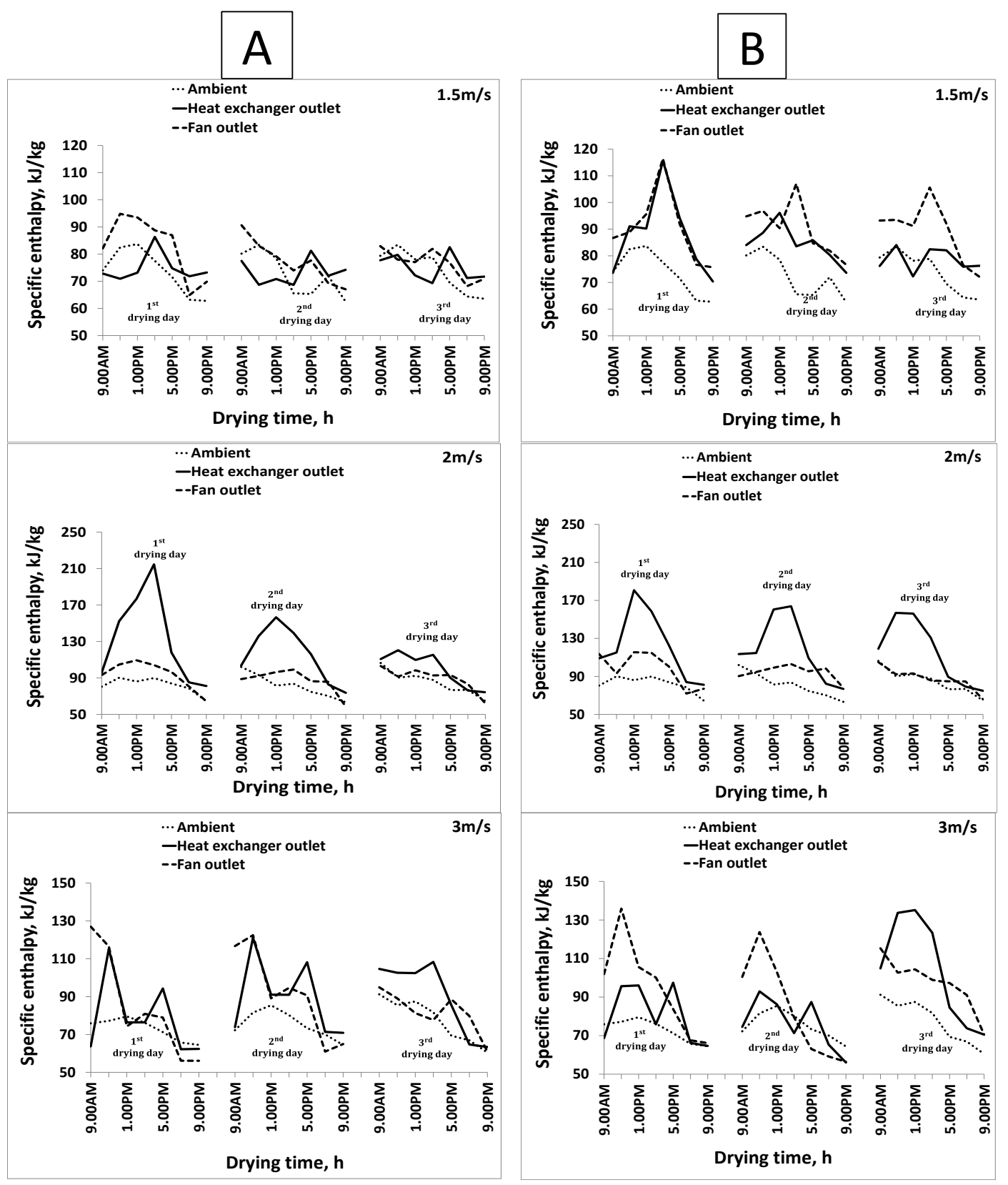

Figure 15. Specific enthalpy of the drying air as affected by drying time at different drying air velocities for both parallel (A) and counter (B) drier units 


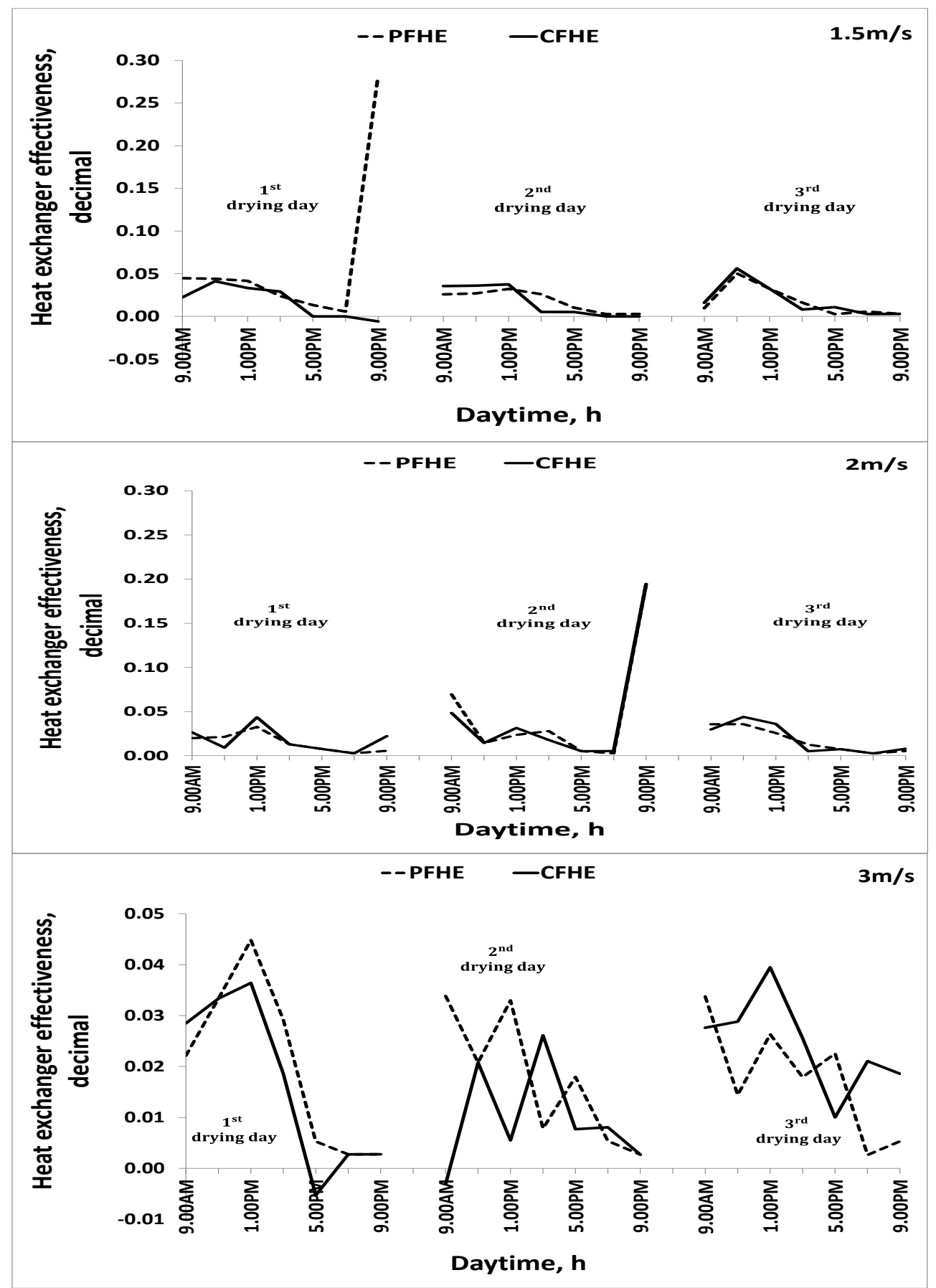

Figure 16. The effect of drying air velocity on the effectiveness of heat exchanger for both parallel and counter flow heat exchangers 

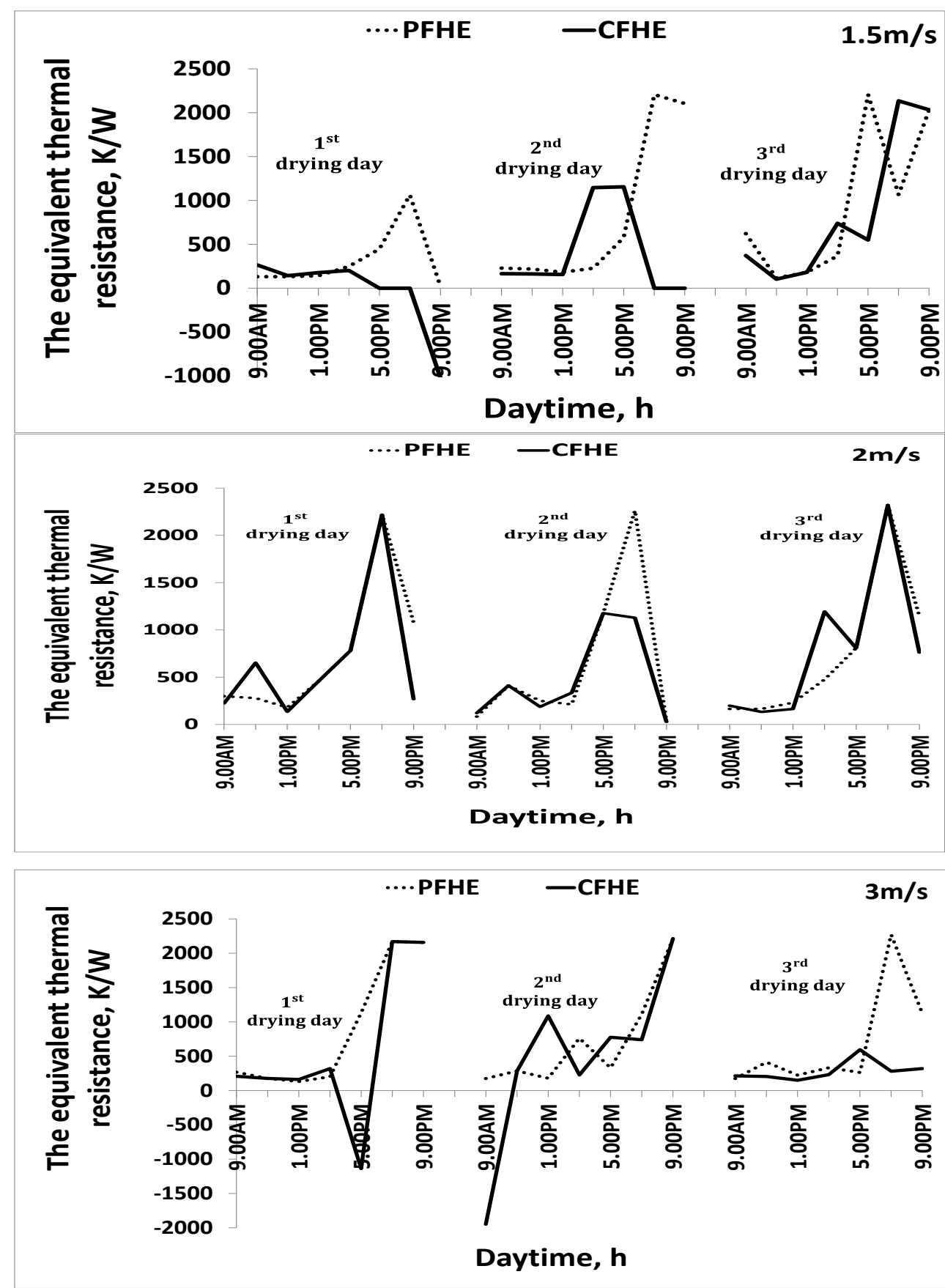

Figure 17. The changes occurred in thermal resistance during heat transfer process through both of parallel and counter flow heat exchangers 
Figure 18 shows the relationship between the heat energy transferred against daytime for the three drying air velocities under study. For the first drying day and parallel flow heat exchanger, the heat energy transferred was of $0.77,1.71$ and $1.81 \mathrm{~kW}$ at drying air velocities of $1.5,2$ and $3 \mathrm{~m} / \mathrm{s}$, respectively.

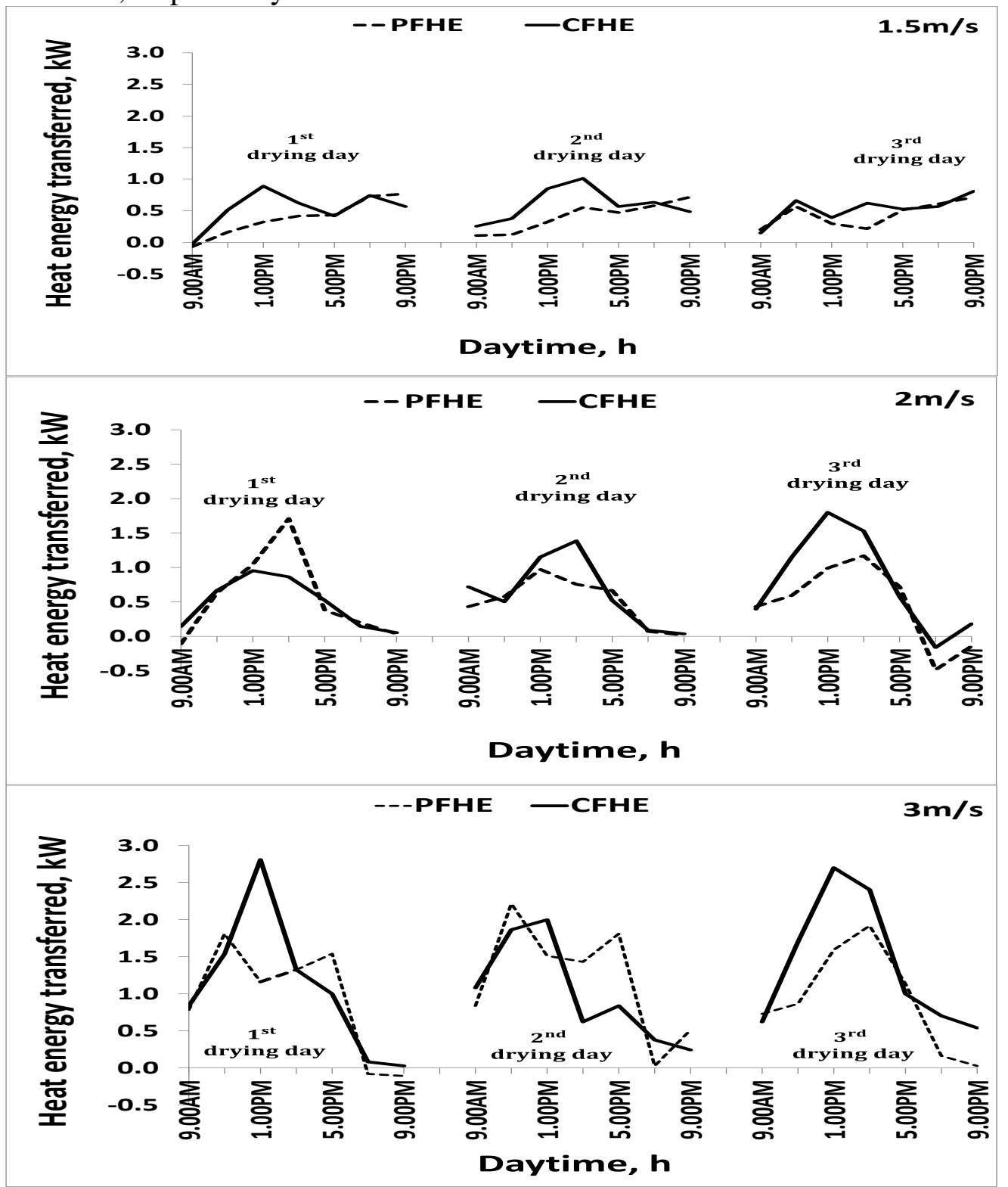

Figure 18. Heat energy transferred through the tube to the drying air in parallel and counter flow heat exchangers 
In contrast, for the counter flow heat exchanger and first drying day, the heat energy transferred was of $0.89,0.96$ and $2.81 \mathrm{~kW}$ at $1.5,2$ and $3 \mathrm{~m} / \mathrm{s}$ drying air velocity, respectively. Moreover, for the second and third drying days, the heat energy transferred behaves the same. In general, the maximum of thermal energy transferred from water to air of $2.21 \mathrm{~kW}$ and $2.81 \mathrm{~kW}$ for the parallel and counter flow heat exchangers, respectively. Figure 19 shows the maximum mass loss of the fish wastes for the three drying air velocities under study.

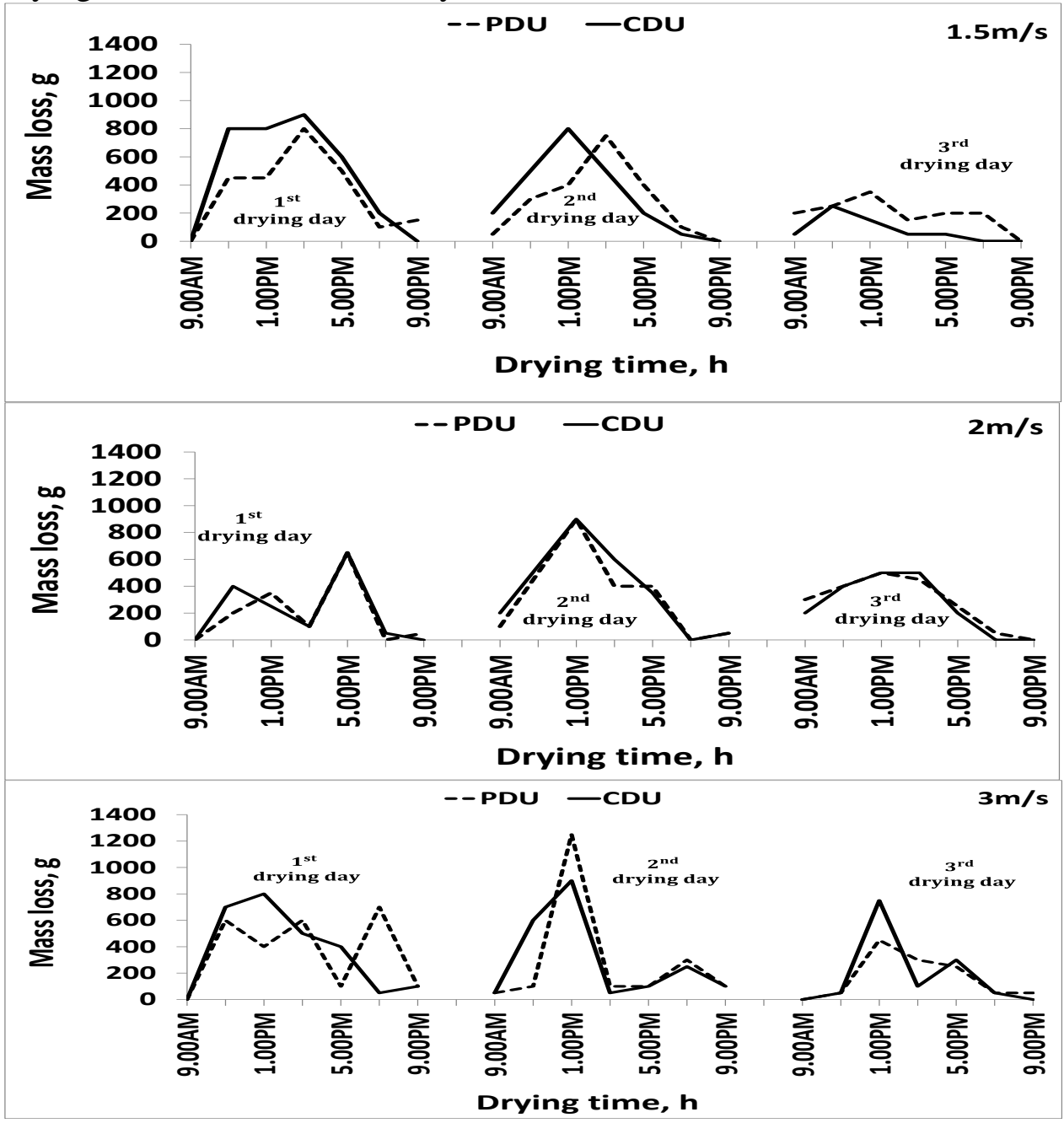

Figure 19. Changes of mass loss of fish farm wastes against drying time at different drying air velocities for the parallel and counter flow heat exchangers 
For the first drying day and parallel drier unit, the mass loss of the wastes was of 800,650 and $700 \mathrm{~g}$ at drying air velocities of $1.5,2$ and $3 \mathrm{~m} / \mathrm{s}$, respectively. In contrast, for the counter drier unit and first drying day, the mass loss of the wastes was of 900,850 and 800 at 1.5, 2 and $3 \mathrm{~m} / \mathrm{s}$ drying air velocity, respectively. Moreover, for the second and third drying days, the mass loss of fish wastes behaves the same. It was found that the mass loss of fish wastes is higher for the counter drier unit than that of the parallel one. Table 1 shows the final mass and the mass reduction percentage in each of the parallel and counter systems. Each treatment was replicated three times.

Table 1. Mass of fish wastes before and after drying

\begin{tabular}{|c|c|c|c|c|c|}
\hline $\begin{array}{l}\text { Drying } \\
\text { system }\end{array}$ & $\begin{array}{l}\text { Drying air } \\
\text { velocity, } \\
\text { m/s }\end{array}$ & $\begin{array}{c}\text { Initial } \\
\text { mass, } \\
\text { kg }\end{array}$ & $\begin{array}{c}\text { Final } \\
\text { mass, } \\
\text { kg }\end{array}$ & $\begin{array}{c}\text { Time } \\
\text { taken, } \\
\text { day }\end{array}$ & $\begin{array}{c}\text { Mass } \\
\text { reduction, } \\
\%\end{array}$ \\
\hline \multirow{3}{*}{$\begin{array}{c}\text { Parallel } \\
\text { drier unit }\end{array}$} & 1.5 & \multirow[b]{3}{*}{7} & 1.20 & \multirow{6}{*}{3} & 17.14 \\
\hline & 2 & & 1.35 & & 19.28 \\
\hline & 3 & & 1.35 & & 19.28 \\
\hline \multirow{3}{*}{$\begin{array}{l}\text { Counter } \\
\text { drier unit }\end{array}$} & 1.5 & \multirow[b]{3}{*}{7} & 0.90 & & 12.86 \\
\hline & 2 & & 1.10 & & 15.71 \\
\hline & 3 & & 1.15 & & 16.43 \\
\hline
\end{tabular}

Chemical composition of dried fish wastes is presented in Table 2.

Table 2. Chemical composition of dried fish wastes

\begin{tabular}{|c|c|c|c|c|c|c|}
\hline Item & $\begin{array}{c}\text { Dry } \\
\text { matter, } \\
\text { \% }\end{array}$ & $\begin{array}{c}\text { Crude } \\
\text { protein, } \\
\%\end{array}$ & $\begin{array}{c}\text { Crude fat, } \\
\%\end{array}$ & $\begin{array}{c}\text { Crude } \\
\text { fiber, } \\
\%\end{array}$ & $\begin{array}{c}\text { Carbohydrates, } \\
\%\end{array}$ & $\begin{array}{c}\text { Ash, } \\
\%\end{array}$ \\
\hline $\begin{array}{c}\text { Moisture } \\
\text { content, } \\
\text { \%wb }\end{array}$ & 85.89 & 50.04 & 8.13 & 0.43 & 9.05 & 18.24 \\
\hline $\begin{array}{c}\text { Moisture } \\
\text { content, } \\
\text { \% db }\end{array}$ & 100 & 58.26 & 9.46 & 0.51 & 10.53 & 21.24 \\
\hline
\end{tabular}




\section{CONCLUSIONS}

The experiment was conducted on drying fish ponds wastes. The effect of different drying air velocities of $1.5,2$, and $3 \mathrm{~m} / \mathrm{s}$ on two types of heat exchangers (parallel and counter) was studied. The parallel and counter drier units have the ability to dry fourteen kilograms of small fish with a thin layer where moisture content of the fish wastes was $76.9 \pm 1 \%$ wb. The drying air temperature and outlet from the fan in the parallel system ranged from 33 to $43.9^{\circ} \mathrm{C}$, and in the counter system, ranged from 34 to $45.8^{\circ} \mathrm{C}$ and therefore outlet air from the fan can be used again for the drying process. The most important results could be summarized as follows:

1. The drying air velocity of $1.5 \mathrm{~m} / \mathrm{s}$ has achieved the drying rate of 0.283 and $0.420 \mathrm{~kg}$ water $/(\mathrm{kg}$ dry matter. min) for the parallel and counter drier units, respectively.

2. Drying time decreases with the increase of drying air temperature and the type of heat exchangers (parallel and counter) represents a significant impact on the drying process of fish farm wastes.

3. The final moisture content of 11.43 and $6.43 \% \mathrm{wb}$ is reached after three days of drying for the parallel and counter drier units, respectively at drying air velocity of $1.5 \mathrm{~m} / \mathrm{s}$.

4. The drying air velocity of $3 \mathrm{~m} / \mathrm{s}$ has achieved the highest heat energy transferred rate from water to air of 2.21 and $2.81 \mathrm{~kW}$ for the parallel and counter flow heat exchangers, respectively.

5. The thermal resistance of the counter flow heat exchanger is less than that of the parallel one for all the drying air velocities.

6. The maximum effectiveness of heat exchanger was of $28 \%$ at $1.5 \mathrm{~m} / \mathrm{s}$ for the parallel drier unit, but it was of $20 \%$ at $2 \mathrm{~m} / \mathrm{s}$ for the counter one.

7. Moisture content decreases tremendously with the evolution of drying time, where the reduction rates of fish wastes moisture content for counter drier unit were higher in comparison with parallel one throughout the drying process.

8. The highest internal energy of water tank is $6.09 \mathrm{~kJ}$ at $5.00 \mathrm{PM}$, temperature of water is $40.6^{\circ} \mathrm{C}$ and less radiation is $77.43 \mathrm{~W} / \mathrm{m}^{2}$. 
9. The counter flow system has achieved the highest exergy rate of $0.433 \mathrm{~kW}$ at the drying air velocity of $3 \mathrm{~m} / \mathrm{s}$ and the parallel system is $2.49 \mathrm{~kW}$ at drying air velocity of $2 \mathrm{~m} / \mathrm{s}$.

10. Specific enthalpy of drying air of counter drier unit is higher than that of parallel one at drying air velocities of 1.5 and $3 \mathrm{~m} / \mathrm{s}$ while lower at drying air velocity of $2 \mathrm{~m} / \mathrm{s}$.

11. Latent specific enthalpy of the ambient air is less than the sensible specific enthalpy of the air outside the parallel and counter systems.

\section{REFERENCES}

Abdallah, S. E. 1999. Utilization of solar energy in agricultural purposes: Applications of solar energy collected by a plastic greenhouse for drying and aerating of wheat crop. Unpublished M. Sc. thesis, Department of Agricultural Mechanization, Faculty of Agriculture, Kafr Elsheikh, Tanta University, Egypt.

Abdallah, S. E. 2010. Thermal efficiency enhancement of a solar drier for hay making from sugar beet tops. AMA-Agricultural Mechanization in Asia Africa and Latin America, 41(4): 87-98.

Abou- Zaher, S. E. 1998. Environmental control systems of agricultural structure: A simulation study on broiler housing systems. Unpublished $\mathrm{Ph}$. D. thesis, Department of Agricultural Mechanization, Faculty of Agriculture, Kafr ElSheikh, Tanta University, Egypt.

Afriyie, J. K.; M. A. A. Nazha; H. Rajakaruna and F. K. Forson. 2009. Experimental investigations of a chimney-dependent solar crop drier. Renewable Energy, 34: 217-222.

Agarwal, P.; A. Sikand and V. Shanthi. 2014. Application of heat exchangers in bioprocess industry: a review. International Journal of Pharmacy and Pharmaceutical Sciences, 6(1): 24-28.

Ali, M. F. 1996. The use of treated and untreated sugar beet by-products in feeding farm animals. Unpublished $\mathrm{Ph}$. D. thesis, Faculty of Agriculture, Kafr Elsheikh, Tanta University, Egypt.

AOAC. 2005. Association of Official Analytical Chemists, Official Methods of Analysis (18th Ed.). International, Maryland, USA. 
Arason, S. 2001. The drying of fish and utilization of geothermal energy The icelandic experience. Keynote lectures. 1st Nordic drying conference, Trondheim, 27th - 29th June 2001. Published in the conference's CD-disk.

Bala, B. K. and M. R. A. Mondol. 2001. Experimental investigation on solar drying of fish using solar tunnel drier. Drying Technology, 19: 427-436.

Bala, B. K and N. Debnath. 2012. Solar drying technology: potentials and developments. Journal of Fundamentals of Renewable Energy and Applications, Vol. 2, Article ID R120302, 5page.

Bala, B. K.; M. R. A. Mondol; B. K. Biswas and B. L. Das Chowdury. 2001. Solar drying of pineapple using solar tunnel drier. 4th International Conference on Mechanical Engineering, 26-28, Dhaka, Bangladesh, pp: 47-51.

Banout, J. P. Ehl; J. Havlik; B. Lojka; Z. Polesny and V. Verner. 2011. Design and performance evaluation of a double-pass solar drier for drying of red chilli (Capsicum annum L.). Solar Energy, 85: 506515.

Basunia, M. A.; H. H. Al-Handali; M. I. Al-Balushi; M. S. Rahman and O. Mahgoub. 2011. Drying of fish sardines in Oman using solar tunnel driers. Journal of Agricultural Science and Technology, B1: 108-114.

Budihardjo, I. and G. L. Morrison. 2009. Performance model for waterin-glass evacuated tube solar water heaters. Solar Energy, 83: 49-56.

Bukola, O. Bolaji and Ayoola P. Olalusi. 2008. Performance evaluation of a mixed-mode solar drier, Assumption University Journal of Technology, 11(4): 225-231.

Darvishi, H.; M. Azadbakht; A. Rezaeiasl and A. Farhang. 2013. Drying characteristics of sardine fish dried with microwave heating. Journal of the Saudi Society of Agricultural Sciences, 12: 121-127. 
Dhiwahar, Er. M. 2010. Solar for fish and vegetables, Shri AMM Murugappa Chettiar Research Centre. Taramani, Chennai- 600113. http://www.amm-mcrc.org. Accessed on 24/3/2014.

Edwards, P.; L. A. Tuan and G. L. Allan. 2004. A survey of marine trash fish and fishmeal as aquaculture feed ingredients in Vietnam, ACIAR Working Paper No. 57, Australian Centre for International Agricultural Research, Canberra, Australia.

Ekechukwu, O. V and B. Norton. 1999. Review of solar energy drying III: low temperature air-heating solar collectors for crop drying applications. Energy Conversion and Management, 40(6): 657-667.

Elbadawy, E. I. A. 2016. Solar energy applications in the field of agricultural process engineering: Technology of drying crop residues by solar energy. Unpublished M. Sc. thesis, Department of Agricultural Engineering, Faculty of Agriculture, Kafrelsheikh University, Egypt.

Eldreeny, A. G. F. 2015. Process engineering of agricultural and industrial wastes: Engineering aspects for processing agricultural and industrial wastes. Unpublished M. Sc. thesis, Department of Agricultural Engineering, Faculty of Agriculture, Kafrelsheikh University, Egypt.

El-Keway, A. A. 2003. Utilization of solar heated and ambient air for drying rough rice for several harvest periods. Unpublished $\mathrm{Ph}$. D. thesis, Department of Agricultural Mechanization, Faculty of Agricultural, Kafr Elsheikh, Tanta University, Egypt.

El-Sahrigi, A. F.; M. A. El-Refaie; S. M. Abdelatif and O. K. Mohamed. 1993. Utilization of solar energy in agricultural crop drying. Misr Journal of Agricultural Engineering, 10(3): 402-417.

Fakheri, A. 2006. Thermal efficiency of the cross flow heat exchangers. Proceedings of the 2006 American Society of Mechanical Engineers (ASME), International Mechanical Engineering Congress and Exposition (IMECE), Chicago, IL, November 5-10. 
FAO. 2014. Food and Agriculture Organization of the United Nations. The State of World Fisheries and Aquaculture 2014. http://www.fao.org/3/a-i3720e.pdf. Accessed on 17/10/2016.

FAO. 2016. Food and Agriculture Organization of the United Nations. The State of World Fisheries and Aquaculture 2016. http://www.fao.org/3/a-i5555e.pdf. Accessed on 23/12/2016.

FWA. 2010. Fish Wealth Authority. http://grfrd.org.com. Accessed on 20/11/2016.

Forson, F. K., M. A. A. Nazha and H. Rajakaruna. 2007. Modeling and experimental studies on a mixed-mode natural convection solar crop drier. Solar Energy; 81(3): 346-357.

Fudholi, A.; K. Sopian; M. H. Ruslan; M. A. Alghoul and M. Y. Sulaiman. 2010. Review of solar driers for agricultural and marine products. Renewable and Sustainable Energy Reviews, 14(1): 1-30.

Gatea, A. A. 2011. Design and construction of a solar drying system, a cylindrical section and analysis of the performance of the thermal drying system. African Journal of Agricultural Research, 6(2): 343351.

Gbaha, P.; H. Yobouet Andoh; J. Kouassi Saraka; B. Kamenan Koua and S. Toure. 2007. Experimental investigation of a solar drier with natural convective heat flow. Renewable Energy, 32(11): 18171829.

Goddard, J. S. and J. S. M. Perret. 2005. Co-drying fish silage for use in aquafeeds. Animal Feed Science and Technology, 118: 337-342.

Gudlaugsson, B. 1998. Utilization of geothermal energy for freeze drying. IFL report, 2-98, Icelandic fisheries Lab. (in Icelandic).

Guo, Z. Y.; X. B. Liu.; W. Q. Tao and R. K. Shah. 2010. Effectivenessthermal resistance method for heat exchanger design and analysis. International Journal of Heat and Mass Transfer, 53: 2877-2884.

Incropera, F. P. D and P. DeWitt. 2002. Fundamentals of heat and mass transfer. $5^{\text {th }}$ ed., Wiley, New York, USA.

Jairaj, K. S.; S. P. Singh and K. Srikant. 2009. A review of solar driers developed for grape drying. Solar Energy, 83: 1698-1712. 
Kakac, S and H. Liu. 2002. Heat exchangers selection, rating, and thermal design. $2^{\text {nd }}$ ed; Boca Raton: CRC Press, pp. 33-45.

Knapp, G. 2008. The potential for increasing production of fishmeal and fish oil from food fishery byproducts: the case of Alaska pollock. International fishmeal and fish oil organization annual conference San Diego, California, USA.

Leon, M. A.; S. Kumar and S. C. Bhattacharya. 2002. A comprehensive procedure for performance evaluation of solar food driers. Renewable and Sustainable Energy Reviews, 6: 367-393.

López-Mosquera, M. E.; E. Fernandez-Lema; R. Villares; R. Corral; B. Alonso and C. Blanco. 2011. Composting fish waste and seaweed to produce a fertilizer for use in organic agriculture. Procedia Environmental Sciences, 9: 113-117.

MAF. 1995. Ministry of Agriculture and Fisheries. Directorate Annual Statistics Report, Oman.

Marco, R.; B. Enrico; M. Emanuele; M. Andrea; V. Mauro and N. Vincenzo. 2015. Experimental tests of solar collectors prototypes systems. Energy Procedia, 82: 744-751.

Michael Ayodele, O. and O. Adesoji Matthew. 2012. Effects of pretreatments and drying temperatures on drying rate and quality of African Catfish (Clarias gariepinus). Journal of Biology, Agriculture and Healthcare, 2(4): ISSN 2224-3208.

Mujaffar, S. and C. K. Sankat. 2011. The Effect of temperature on the drying characteristics of salted Shark Fillets, The West Indian Journal of Engineering, 33(1-2): 19-25.

Mumba, J. 1996. Design and development of a solar grain drier incorporating photovoltaic powered air circulation. Energy Conversion and Management, 37(5): 615-621.

Montero, I.; J. Blanco; T. Miranda; S. Rojas and A. R. Celma. 2010. Design, construction and performance testing of a solar drier for agroindustrial by-products. Energy Conversion and Management, 51: $1510-1521$. 
Olokor, J. O., C. Ugoala and A. Ibitoye. 2009. Study of weight loss in solar drier across different ecological zones of Nigeria. Nature Proceedings: Nature Proceedings: doi:10.1038/npre.2009.3018.1: Posted2 Apr 2009.

Pangavhane, D. R.; R. L. Sawhney and P. N. Sarsavadia. 2002. Design, development and performance testing of a new natural convection solar drier. Energy, 27: 579-590.

Ramana Murthy, M. V. 2009. A review of new technologies, models and experimental investigations of solar driers. Renewable and Sustainable Energy Reviews, 13(4): 835-844.

RIMF. 2001. Research Institute for Marine Fisheries. Proceedings of marine fisheries research, Volume 2, the 40th anniversary of Research Institute for Marine Fisheries Foundation (1961-2001). Ministry of Fisheries and Agriculture Publishing House, 548pp. Hanoi, Vietnam.

Russ, W. and R. M. Pittroff. 2004. Utilizing waste products from the food production and processing industries. Critical Reviews in Food Science and Nutrition, 44: 57-62.

Sablani, S.; M. S. Rahman; O. Mahgoub and A. Al-Marzouki. 2003. Drying rates and quality parameters of fish sardines processed using solar driers. Agricultural and Marine Sciences, 8(2): 79-86.

Sankat, C. K. and S. Mujaffar. 2004. The sun and solar drying potential of salted shark fillets. International Drying Symposium (IDS), 37: 1584-1591, Sao Paulo City, Brazil.

Sharma, A.; C. R. Chen and N. V. Lan. 2009. Solar-energy drying systems: A review. Renewable and Sustainable Energy Reviews, 13: $1185-1210$.

Sultana, S.; Shikha; M. N. Islam and M. Kamal. 2009. Drying performance of rotating and solar tunnel drier for production of quality dried fish. Progress in Agriculture, 20(1\&2): 173-181.

Vijaya Venkata Raman, S.; S. Iniyan and R. Goic. 2012. A review of solar drying technologies. Renewable and Sustainable Energy Reviews, 16: 2652-2670. 
Vlachos, N. A.; T. D. Karapantsios; A. I. Balouktsis and D. Chassapis. 2002. Design and testing of a new solar tray drier. Drying Technology, 20(5): 1239-1267.

Westendorf, M. 2000. Food waste to animal feed. Iowa State Press, Iowa, USA.

WFC. 2011. World Fish Center. Strategy Update, 2011. The World Fish Center, Penang, Malaysia.

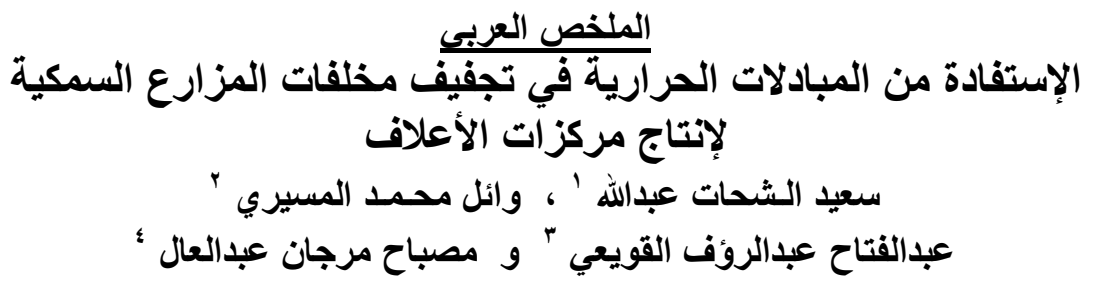

يولا إرتفاع أسعار الأعلاف الحيوانية والسمكية في مصر فجوة كبيرة في مجال التخذية، حيث

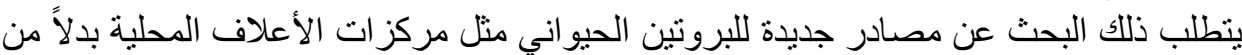

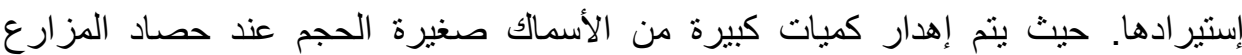

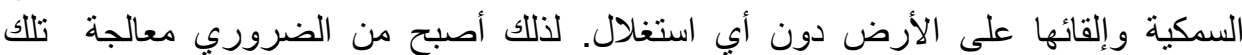

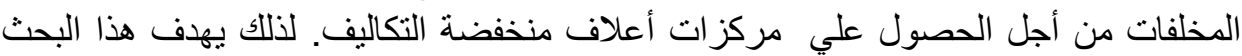

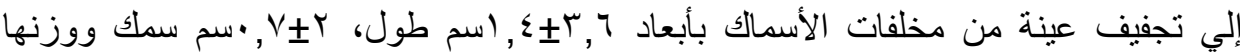
9

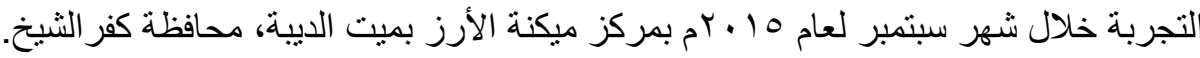
الهدف العام من الدراسة الحالية هو الإستفادة من المبادلات الحراتية العراتية في تحسين الكفاءة

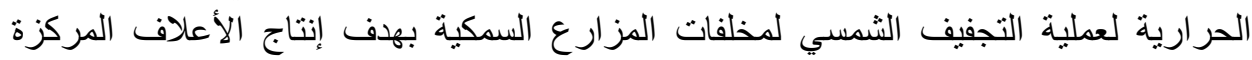

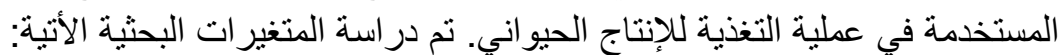

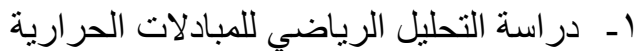

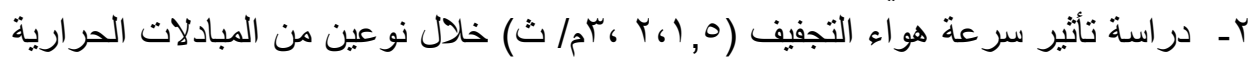

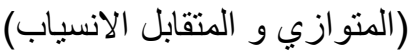

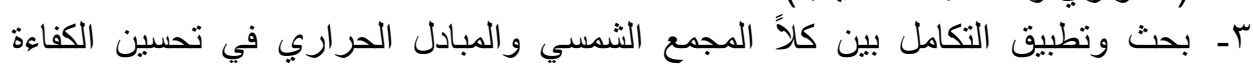

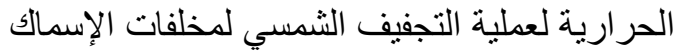

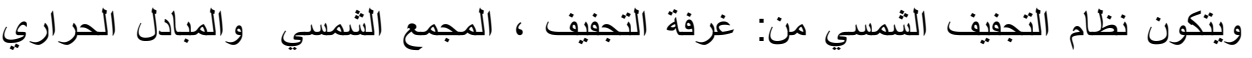

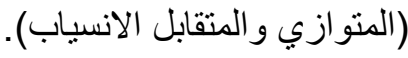

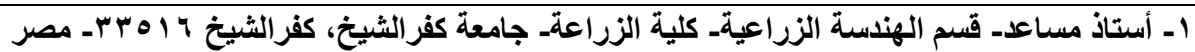

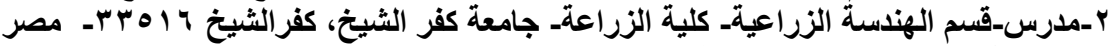

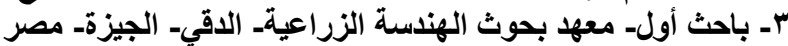

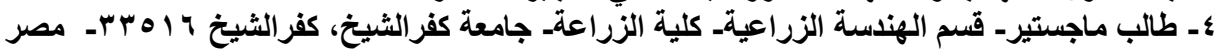


ا ـ المجفات الثمسية من نوع الصوبة

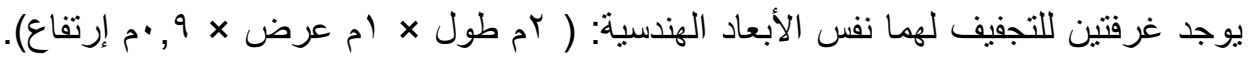
وتم تغطية جميع الجوانب من البلاستيك البولي إثيلين، وضعت تحت التع الظل لتجنب تأثثر أثنعة الثمس المباثرة علي غرفة التجفيف من أجل در اسة أداء المبادلات الحرارية. ويتم تعليق غرفة وفئ التجفيف بواسطة خلية الوزن لمعرفة الوزن الكلي لغرفة التجفيف، ثم يتم توصبل المبادل درل

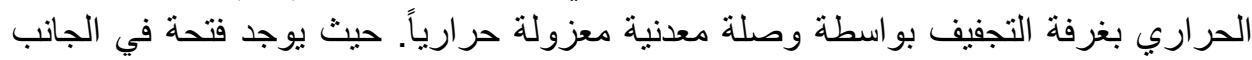
الآخر في أسفل غرفة التجفيف ويثبت عليها مروحة لسحب بخار الماء الساخن الناتج عن عملية

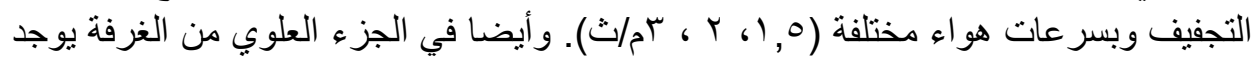
فتحه لدخول الهواء الساخن الناتج من المبادل الحراري بحيث يمر الهواء الساخن لتجفيف مخلفات الأسماك.

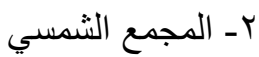
المجمع الثمسي عباره عن إطار خشبي مسطح أبعاده (1 × ( م) ويتم تغطيتة بلوح زجاجي شفاف سمكه آمم وبداخله لوح ماص مطلي باللون الداكن لامتصاص أشعة الثمس، ثم ينم

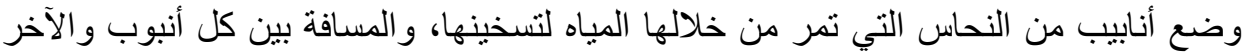

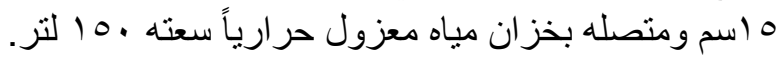
بـ المبادل الحراري

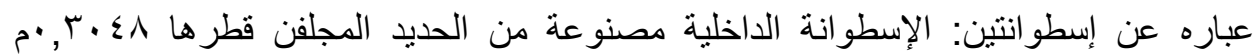

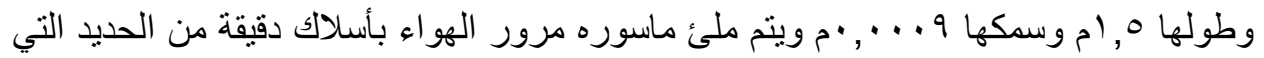

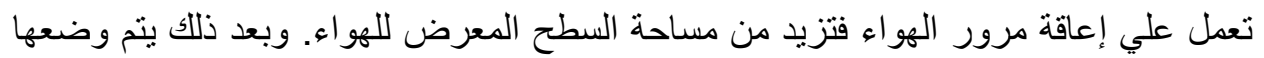
داخل إسطو انة أخرى قطر ها ْ, •م حيث يمر بها الماء الساخن، وبعد ذللك يتم عزل المبادل الحراري من الخارج بالصوف الزجاجي سواء يمر الهواء في نفس إتجاه المياه أو في الإتجاه المعاكس.

ع - مخلفات الأسماك تم الحصول على مخلفات الأسماك (الأسمالك الصغيرة) من المزارع السمكية من قرية دمرو، مركز سيدي سالم، بمحافظة كفر الثيخ. ثم نقلها إلى مركز ميكنة الأرز بميت الديبة، محافظة

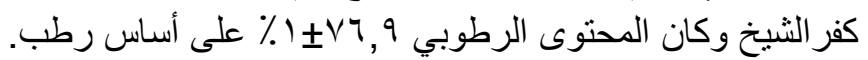

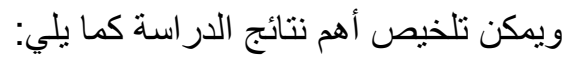
ا - عقت سر عة هو اء التجفيف 0, ام/ث أقصي معدل تجفيف لنظامي المتوازي و المتقابل

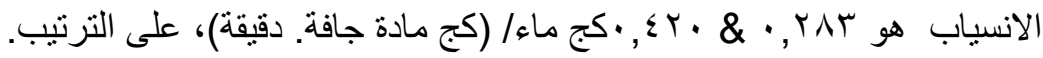

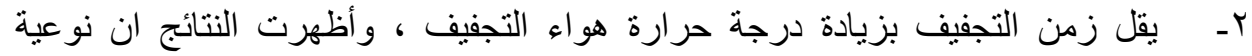

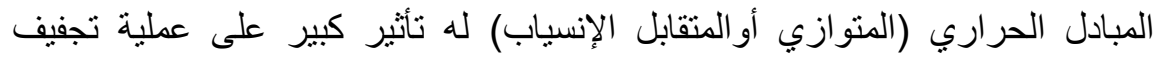
مخلفات الأسماك.

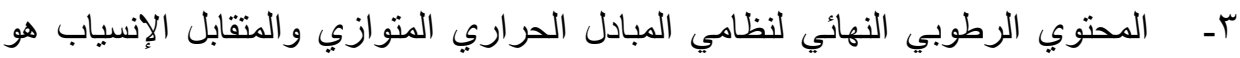

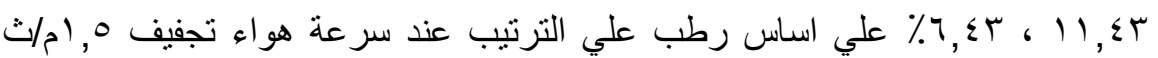
و التي أجربت في ثناثة أيام تجفيف. 


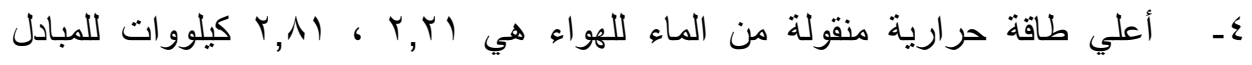

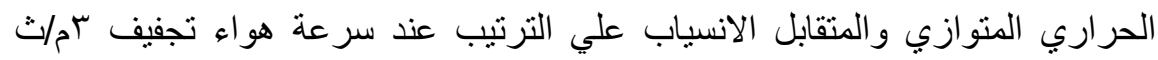

$$
\text { مقارنة بسر عات الهواء الأخري. }
$$

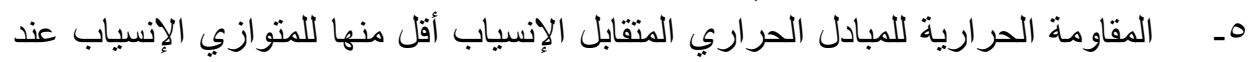

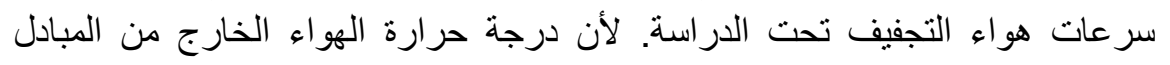

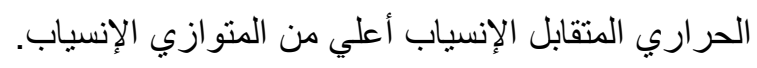

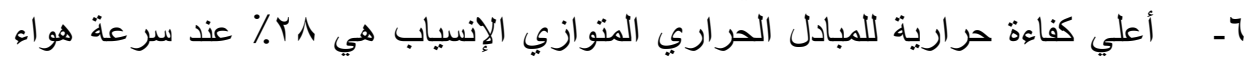

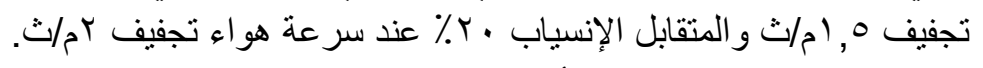

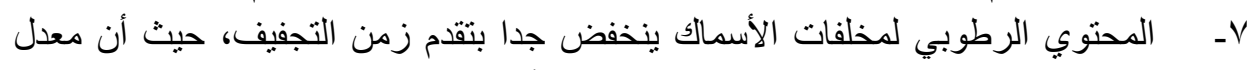

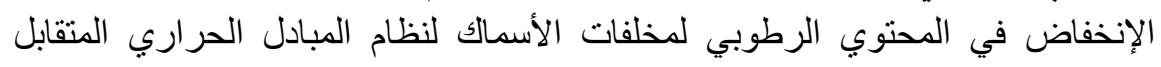

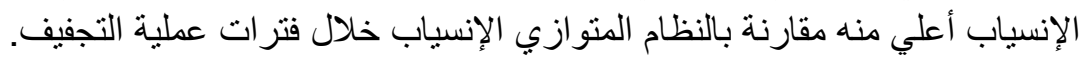

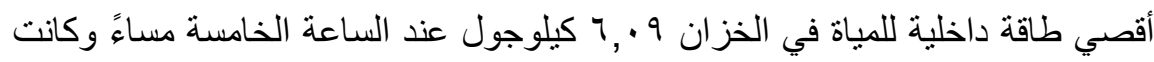

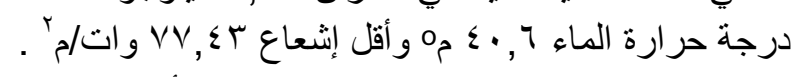

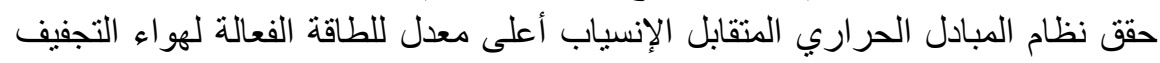

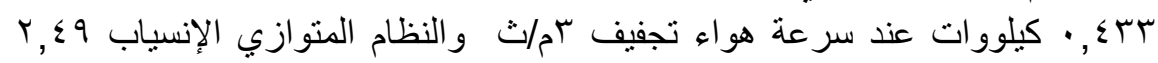

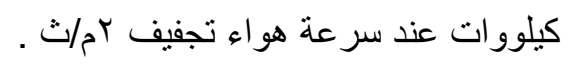
• 1ـ الإنثالبيا النوعية لهواء التجفيف لوحدة النظام المتقابل الإنسياب أعلي من الإنثالبيا

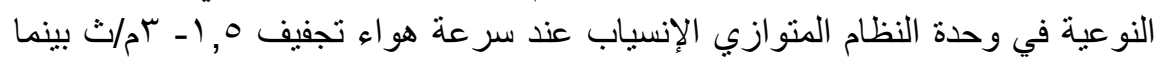

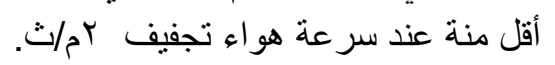

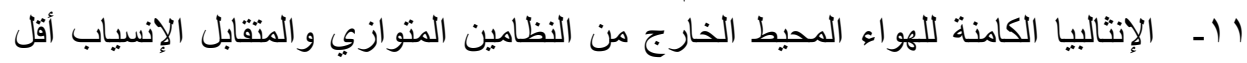

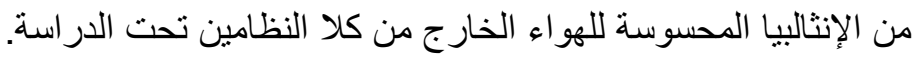

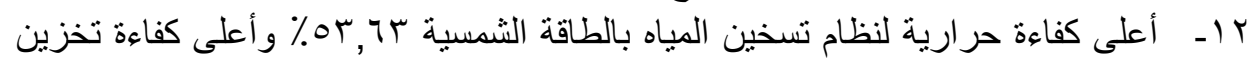

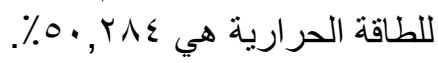

